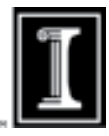

Institute of Natural Resource Sustainability

\title{
Vascular Plant Communities of the Green River Lowlands in Northwestern Illinois
}

John E. Ebinger, Loy R. Phillippe, William C. Handel, Connie J. Cunningham, William E. McClain, Randy N. Nyboer, and Todd Bittner 


\section{I L L L I N O I I S}

Institute of Natural Resource Sustainability

William Shilts, Executive Director

Illinois Natural History Survey

Brian D. Anderson, Director

Forbes Natural History Building

1816 South Oak Street

Champaign, Illinois 61820

217-333-6880

Citation:

Ebinger, J.E., L.R. Phillippe, W.C. Handel, C.J. Cunningham, W.E. McClain, R.N. Nyboer, and T. Bittner. 2009. Vascular plant communities of the Green River Lowlands in northwestern Illinois. Illinois Natural History Survey Bulletin 39(2):39-78.

Science editor: Jeff Levengood

Production editor: Charles Warwick

US ISSN 0073-4918

US ISBN 1-882932-23-4

Printed by authority of the University of Illinois

(C) 2009

PO\# $8073131-.45 \mathrm{M}-10-09$

Printed with soy ink on recycled and recyclable paper.

The University of Illinois will not engage in discrimination or harassment against any person because of race, color, religion, national origin, ancestry, age, marital status, disability, sexual orientation including gender identity, unfavorable discharge from the military or status as a protected veteran and will comply with all federal and state nondiscrimination, equal opportunity and affirmative action laws, orders and regulations. This nondiscrimination policy applies to admissions, employment, access to and treatment in University programs and activities.

University complaint and grievance procedures provide employees and students with the means for the resolution of complaints that allege a violation of this Statement. Inquiries or complaints may be addressed to the Director and Assistant Chancellor, Office of Equal Opportunity and Access, 601 East John Street, Swanlund Administration Building, (217) 333-0885, fax (217) 244-9136, TTY (217) 244-9850 or the Associate Provost and Director, Academic Human Resources, Henry Administration Building, (217) 333-6747, fax (217) 244-5584. For other University of Illinois information, contact University Directory Assistance at 333-1000. 


\section{Vascular Plant Communities of the Green River Lowlands in Northwestern Illinois}

John E. Ebinger ${ }^{1}$, Loy R. Phillippe ${ }^{1}$, William C. Handel ${ }^{1}$,

Connie J. Cunningham ${ }^{1}$, William E. McClain ${ }^{1}$, Randy N. Nyboer ${ }^{1}$, and Todd Bittner ${ }^{2}$

1. Illinois Natural History Survey

1816 S. Oak St., Champaign, IL 61820

2. Illinois Department of Natural Resources: Current addressCornell Plantations, 1 Plantations Rd., Ithaca, NY 14850

Correspondence to:

John E. Ebinger

Illinois Natural History Survey

1816 S. Oak St.,

Champaign, IL 61820

217-581-3624

jeebinger@eiu.edu 


\section{Vascular Plant Communities of the Green River Lowlands in Northwestern Illinois}

John E. Ebinger, Loy R. Phillippe, William C. Handel,

Connie J. Cunningham, William E. McClain, Randy N. Nyboer, and Todd Bittner 


\section{CONTENTS}

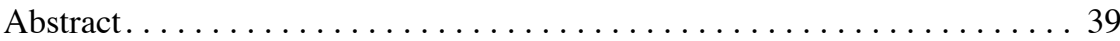

Introduction. . . . . . . . . . . . . . . . . . . . . . . . . . . . . . . . 39

Study Area. . . . . . . . . . . . . . . . . . . . . . . . 40

Methods. ....................................41

Vascular Plant Species and Communities ................41

Ground Layer Sampling. . . . . . . . . . . . . . . . . . . . .41

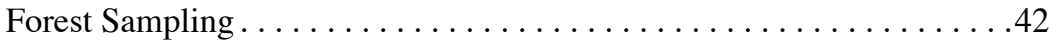

Results................................43

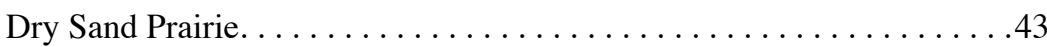

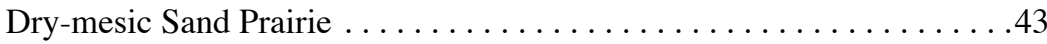

Mesic Sand Prairie . . . . . . . . . . . . . . . . . . . . . . . .43

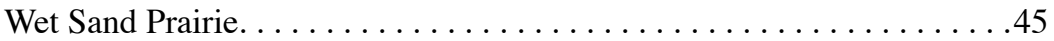

Sedge Meadow..............................45

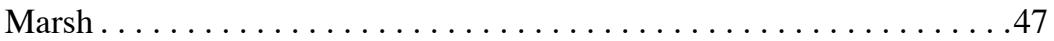

Phalaris Vegetation Zone ....................47

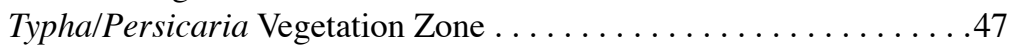

Bolboschoenus fluviatilis Vegetation Zone. . . . . . . . . . . . . . . . . . . . .

Sparganium eurycarpum Vegetation Zone .................49

Carex lacustris/Persicaria coccinea Vegetation Zone . . . . . . . . . . .49

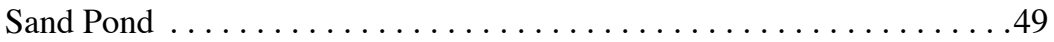

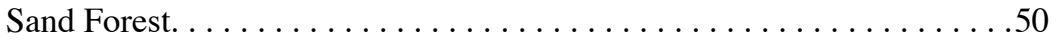

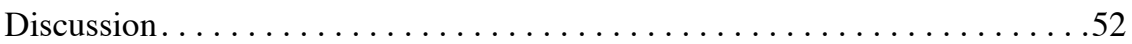

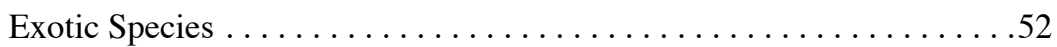

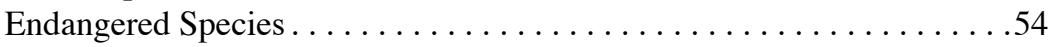

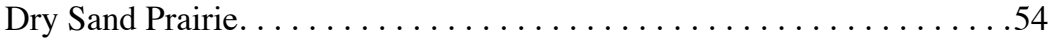

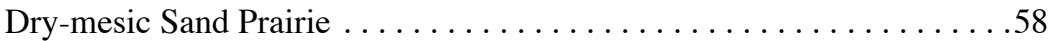

Mesic Sand Prairie...............................59

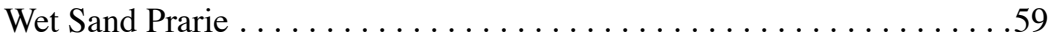

Sedge Meadow. ..............................59

Marsh . . . . . . . . . . . . . . . . . . . . . . . . . . . .59

Sand Forest. . . . . . . . . . . . . . . . . . . . . . . . . . . . . .

Management. ..........................60

Acknowledgments. ............................ 60

Literature Cited . . . . . . . . . . . . . . . . . . . . . .

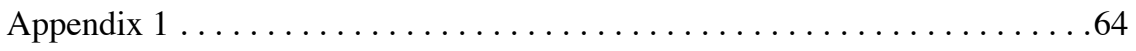




\begin{abstract}
A few high-quality prairies still exist in the sand deposits of the Green River Lowlands. The most extensive remnants are in the Green River State Wildlife Area, Lee County, Illinois. Three upland prairie communities were surveyed; a dry sand prairie dominated by Schizachyrium scoparium, Ambrosia psilostachya, and Amorpha canescens; a dry-mesic sand prairie dominated by Sorghastrum nutans, Schizachyrium scoparium, Antennaria plantaginifolia, and Liatris aspera; and a mesic sand prairie where Sorghastrum nutans and Andropogon gerardii were the dominant grasses, and Parthenium integrifolium, Fragaria virginiana, Liatris pycnostachya, and Euthamia gymnospermoides the common forbs. The lowlands, which included approximately 325 ha, were dominated by the exotic Phalaris arundinacea, but high-quality wet sand prairie, sedge meadow, and marsh communities existed. The wet sand prairies were dominated by Spartina pectinata, Helianthus grosseserratus, and Solidago canadensis; the sedge meadows were dominated by Carex haydenii, Calamagrostis canadensis, and Persicaria coccinea; the marsh communities were divided into distinct vegetation zones. These vegetation zones were surveyed in 2002 and subjected to an extensive uncontrolled fire in 2005. Surveys completed in 2006 and 2007 were used to determine successional changes resulting from the fire. These studies suggested that most communities were returning to the species composition found before the 2005 fire.
\end{abstract}

\section{INTRODUCTION}

Sand deposits are relatively common in the northern half of Illinois, accounting for about $5 \%$ of the land area of the state. Most occur on glacial outwash plains resulting from erosion events associated with Wisconsin glaciation (Wildman and Frye 1970, King 1981). One extensive sand deposit is the Green River Lowlands in parts of Bureau, Henry, Lee, and Whiteside counties in northwestern Illinois. Located just to the west of the terminal moraine of Wisconsin glaciation, extensive amounts of sand and gravel were deposited in these areas during intermittent warm periods of the Wisconsin Episode (Killey 1998). These sands were reworked by wind, creating numerous small sand dune fields (Willman and Frye 1970).

These sand deposits are scattered throughout the Green River Lowland Section of the Grand Prairie Natural Division (Schwegman 1973). This section, which includes the broad valley of the Green River and lower Rock River, was formed about 10,000 years ago during the retreat of Wisconsin glaciation (Willman and Frye 1970). During early European settlement this section had extensive marshes and wet prairies associated with the Great Inlet Swamp that covered part of Lee County (Lyman 1901, McClain 1992, McClain and Ebinger 2000).
Sand deposits containing numerous small dunes were common. Forests and savanna communities grew on the dry sandy ridges, while floodplain forests occurred along the rivers. In recent history, grazing, drainage, and cultivation have disturbed nearly all of this section, while fire suppression has resulted in the formation of many poor-quality sand forests containing numerous early successional and non-native (exotic) species.

Gleason (1910) referred to the vegetation of the Green River Lowlands in his extensive study of the Illinois sand deposits. Until recently that study was the only reference available of the flora of this region. Phillippe et al. $(2000,2003)$ studied some of the sand prairie communities at the Green River State Wildlife Area (GRSWA), Handel et al. (2003) examined the sand prairie remnants and sedge meadows of the Richardson Wildlife Foundation, a private hunting club, and McClain et al. (2003) examined the vegetation of a dune ridge at Foley Sand Prairie Nature Preserve. The purpose of the present study was to determine the composition and structure of the vegetation of the sand communities present in the GRSWA. Also, as the result of an extensive uncontrolled fire in the marsh community of the GRSWA in 2005, we examined the changes in the vegetation of this area in 2006 and 2007. 


\section{STUDY AREA}

The GRSWA, located in the southwestern part of Lee County, about $23 \mathrm{~km}$ south of Dixon, Illinois (S7, S8, S17, S18, T19N R9E and S12, S13 T19N R8E), is the most extensive area in public ownership in the Green River Lowlands (Ebinger et al. 2008) (Fig. 1). The initial purchase of land started in 1938 under the Federal Aid in Wildlife Restoration Act to provide habitat for waterfowl and dwindling populations of the Greater Prairie Chicken (Tympanuchus cupido). Subsequent land purchases increased the size of the GRSWA to 1,025 ha $(2,533$ acres $)$. The area was under intense grazing pressure prior to 1938 , and was subject to much brush encroachment resulting from fire suppression until 1987. Much of the grasslands of the GRSWA were mowed annually from June through September until 1998 (Todd Bittner, personal observations). During the natural areas inventory in the mid-1970s no high-quality natural areas were reported for the GRSWA (White 1978).

Since 1993 an active management program at the GRSWA has been implemented, including burning, brush removal, restoration plantings, and exotic species control. In addition to prescribed fire used to manage the prairie communities, most of the forested areas,

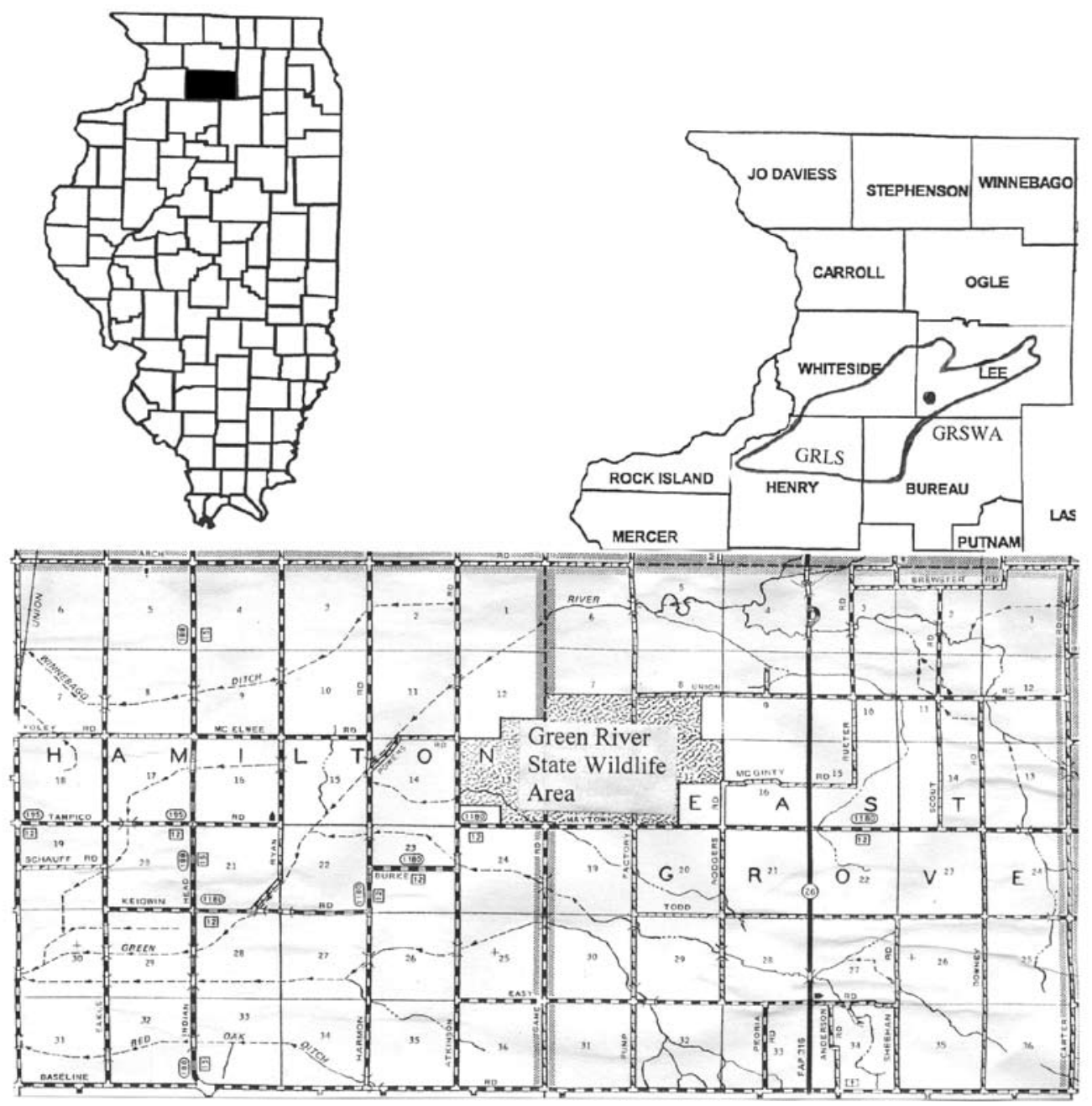

Figure 1. Location of the Green River State Wildlife Area (GRSWA) in the Green River Lowland Section (GRLS) of the Grand Prairie Natural Division, about 24 km south of Dixon, Lee County, Illinois . 
including the woody understory, were removed in the fall and winter of 2001. Beginning in 1987, many of the the dry, dry-mesic, and mesic sand prairies were intentionally burned every one to three years. Presently this multipleuse area is managed for the protection and enhancement of wildlife and natural heritage resources.

The soils of the uplands at the GRSWA are Billett fine sandy loam, Chelsea fine sand, and Sparta loamy sand (Zwicker 1985). These soils, which occur on side slopes and ridges of dunes, are relatively low in organic matter, well drained, and have a surface layer of dark gray to yellow brown friable fine sand. The wetland soils are Adrian muck, Gilford fine sandy loam, Orio mucky sandy loam, and Orio sandy loam. Very high in organic material, these soils occur on level, poorly drained outwash plains and contain surface water for much of the winter and early spring.

On 18 October 2005 the extensive marsh located at the western portion of the GRSWA was burned in an attempt to decrease the growth of the exotic species Phalaris arundinacea (Lavergne and Molofsky 2006). Dry conditions at the time of the controlled burn resulted in extensive peat fires, some of which continued to burn for approximately 30 days. Water was pumped into some areas of the marsh from central pivot irrigation wells located on surrounding farms, and some fires were repeatedly disked and flooded.

The climate in northwestern Illinois is continental with warm summers and cold winters. Based on weather data from Dixon, located near the north-central edge of the Green River Lowlands, the mean annual precipitation is 94.7 $\mathrm{cm}$, June having the highest rainfall $(12.4 \mathrm{~cm})$, and February the lowest $(3.6 \mathrm{~cm})$. Mean annual temperature is $8.5^{\circ} \mathrm{C}$ with the hottest month being July (average of $22.3^{\circ} \mathrm{C}$ ), and the coldest January (average of $-7.9^{\circ} \mathrm{C}$ ). There are an average of 161 frost-free days (Midwestern Regional Climate Center 2008).

\section{METHODS}

\section{Vascular Plant Species and Communities:}

The natural areas studied were visited at various times throughout the growing seasons of 2000 through 2007. Voucher specimens of each plant species were collected, identified, and deposited in the herbarium of the Illinois Natural History
Survey, Champaign, Illinois (ILLS), and the Stover-Ebinger Herbarium of Eastern Illinois University, Charleston, Illinois (EIU). Criteria for designating non-native species followed Mohlenbrock (2002), Gleason and Cronquist (1991), and Taft et al. (1997). Nomenclature follows Mohlenbrock (2002). The plant communities encountered were designated and plotted using the classification system of White and Madany (1978). The locations of threatened and endangered plant species were recorded (Herkert and Ebinger 2002).

The Floristic Quality Index (FQI) was determined for each community type using the coefficient of conservatism (CC) assigned each species based on a species tolerance to disturbance and its fidelity to habitat integrity (Taft et al. 1997). The FQI, therefore, is a weighted index of species richness $(\mathrm{N}=$ number of species present on a site), and is the arithmetic product of the average coefficient of conservatism $(\mathrm{C}$-Value $=$ the average of all species CCs) multiplied by the square root of the species richness $(\sqrt{ } \mathrm{N})$ of an inventory site: $\mathrm{FQI}=\mathrm{C}$-Value $(\sqrt{ } \mathrm{N})$. For relatively small areas that are intensively studied, the FQI gives a rapid means of comparison and an indication of the floristic integrity of the site. Using the FQI along with other floristic measures, such as quadrat-based sampling methods, provide a way to make comparisons among sites. Prairies with an FQI of 35 or higher are considered high-quality natural areas (Taft et al. 1997).

All species recorded for the plots as well as all other species observed in the community were used to determine the FQI of each site.

The Sorensen Index of Similarity (ISs) was used to determine the degree of vegetation similarity among the prairie areas surveyed throughout the Mississippi River sand deposits (Mueller-Dombois and Ellenberg 1974). In this index $[\mathrm{ISs}=2 \mathrm{C} /(\mathrm{A}+\mathrm{B}) \times 100]$, where A equals the number of species in the first community, $B$ equals the number of species in the second community, while $\mathrm{C}$ equals the number of species common between the two communities.

Ground Layer Sampling: In mid-summer of 2003 through 2007 line transects were located randomly along cardinal compass directions within the sand prairies, sedge meadows, and marsh communities. Many of the sites were sampled two or three times during the study; the starting points of each transect were 
marked with metal stakes and relocated using GPS coordinates during each survey. The dry, dry-mesic, mesic, and wet sand prairies were surveyed once (2006), whereas the marsh communities were surveyed in 2002, and again in 2006 and 2007 after a very hot uncontrolled fire burned the marsh in 2005. The sedge meadow located next to a wet sand prairie was surveyed in 2006, and the sedge meadow associated with the marsh in 2002, 2006, and 2007. Two transects were randomly located within each community; along each transect, $1 \mathrm{~m}^{2}$ plots were located at 1- or 5-m intervals (on larger sites the plots were more widely spaced) on alternating sides of the transects $(n=50)$. A random numbers table was used to determine the number of meters ( 0 to 9 ) a plot was located from the transect line. Species cover was determined using the Daubenmire (1959) cover class system as modified by Bailey and Poulton (1968). Only ground layer species rooted within the plot frame were recorded. The modified Daubenmire cover scale is as follows: class $1=0$ to $1 \%$; class $2=>1$ to $5 \%$; class $3=$ $>5$ to $25 \%$; class $4=>25$ to $50 \%$; class $5=>50$ to $75 \%$; class $6=>75$ to $95 \%$; class $7=>95$ to
$100 \%$. Importance value (IV) was determined by summing relative cover and relative frequency. The location of the community study sites are shown in Figure 2 along with extent of the marsh at the GRSWA and the area burned in 2005.

Forest Sampling: In the summer of 2001 the overstory of the forests at the GRSWA were sampled using circular plots 0.3 ha in size, spaced at 25-m intervals along line transects $(\mathrm{n}=10)$. Within each plot all living individuals $\geq 10.0 \mathrm{~cm}$ dbh were identified and diameters recorded. From these data, living-stem density (stems/ha), basal area $\left(\mathrm{m}^{2} / \mathrm{ha}\right)$, relative density, relative dominance, importance value (IV), and average diameter $(\mathrm{cm})$ were calculated for each species. Determination of the IV followed the procedure used by McIntosh (1957), and is the sum of the relative density and relative dominance (basal area). Woody understory composition and density (stems/ha) were determined using nested circular plots $0.0001,0.001$, and 0.01 ha in size, located at 15 -m intervals along randomly located east-west transects within each study area. Four additional 0.0001-ha

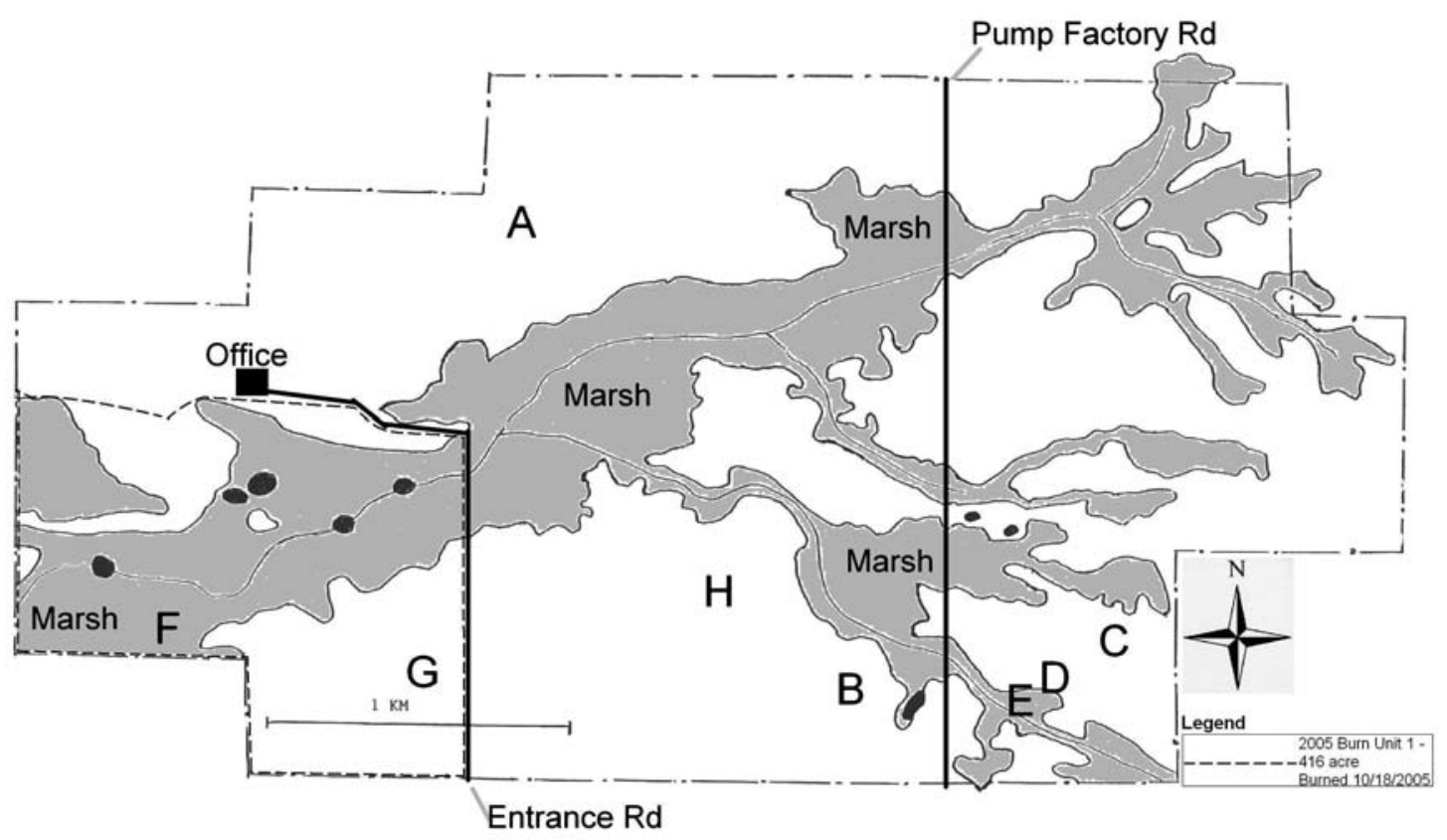

Figure 2. The location of the community studied at the GRSWA along with extent of the marsh and the area burned in 2005. A - dry sand prairie, B - dry-mesic sand prairie, C-mesic sand prairie, D-wet sand prairie, E-sedge meadow (east), F-sedge meadow (west), G-successional lowland, and H-successional upland. 
circular plots were located $6 \mathrm{~m}$ from the center point of each plot along cardinal compass directions. In the 0.0001-ha plots, woody seedlings ( $\leq 50 \mathrm{~cm}$ tall) were counted; in the 0.001-ha circular plots small saplings $(>50 \mathrm{~cm}$ tall and $<2.5 \mathrm{~cm} \mathrm{dbh}$ ) were recorded; and in the 0.01-ha circular plots large saplings $(2.5-<10.0 \mathrm{~cm} \mathrm{dbh})$ were tallied.

During the late fall and winter of 2001, these forested areas, including their woody understory, were removed to reestablish prairie vegetation. The bare sand and woody waste were left on the sites and no prairie seed was planted. The resulting lowland and upland successional communities were examined in 2002, 2003, and 2006. Within each community four transects were randomly located. Along each transect, $1 \mathrm{~m}^{2}$ plots were located at 1-m intervals alternately along transects $(n=100)$. A random numbers table was used to determine the number of meters $(0$ to 9) a plot was located from the transect line. Species cover was determined using the Daubenmire (1959) cover class system as modified by Bailey and Poulton (1968). Importance values were determined by summing relative cover and relative frequency.

Aerial photographs from 1939, 1951, 1970, and 1988 were digitized to determine woody encroachment (trees and large shrubs) at the GRSWA. These aerial photographs were borrowed from the University of Illinois Map Library and scanned with a Microtek ScanMaker. Twentyone stratified random 5-ha sites, approximately $10.12 \%$ of the GRSWA, were interpreted and then digitized using ARC/INFO. The 1939, 1951, and 1970 photographic surveys were all flown in August whereas the 1988 aerial survey was flown in April.

\section{RESULTS}

Dry Sand Prairie: One high-quality dry sand prairie was encountered on the GRSWA (SW1/4 SW1/4 S7 T19N R9E; Fig. 2). This site, approximately 2 ha in size, was located on the ridge and upper slopes of a large stabilized sand dune composed of Chelsea fine sand . The dominant grasses, which did not exceed $1 \mathrm{~m}$ in height, were Schizachyrium scoparium, Koeleria macrantha, Dichanthelium villosissimum, and Leptoloma cognatum. Ambrosia psilostachya ranked second in importance, while other common forbs included Chrysopsis camporum, Solidago nemoralis, and Coreopsis lanceolata (Table1). Amorpha cansecens, Rosa carolina, and Rhus aromati$c a$ were the only woody species encountered in the plots . Based on the Sorensen Index of Similarity the dry sand prairie was very similar to the dry mesic sand prairie, but had no species in common with the sedge meadows (Table 2). Within the dry sand prairie, 48 taxa were recorded in the plots, including 4 exotic species, Achillea millefolium being the most important. Average bare ground and litter was $29 \%$, the vegetation being relatively sparse. A total of 94 species were observed in the dry sand prairie for an FQI of 36.16 and a mean $\mathrm{CC}$ of 3.73 .

Dry-mesic Sand Prairie: On the east side of the GRSWA was a dry-mesic sand prairie on Chelsea fine sand. This sand prairie, covering 3 ha, occupied the dune ridge and upper dune slopes (NE1/4 SW1/4 S17 T19N R9E; Fig. 2). The dominant grasses, which were between 0.9 and $1.3 \mathrm{~m}$ tall, included Sorghastrum nutans and Schizachyrium scoparium. Other relatively common grasses were shorter and included Dichanthelium villosissimum, $D$. oligosanthes, D. perlongum, and Leptoloma cognatum (Table 1). Important forbs included Antennaria plantaginifolia, Liatris aspera, Euthamia gymnospermoides, and Euphorbia corollata. Antennaria plantaginifolia commonly covered small areas in a near monoculture. Based on the Sorensen Index of Similarity, the dry-mesic and mesic prairies were similar but had only a few species in common with the wet prairies and sedge meadows (Table 2). Within the dry-mesic sand prairie, 37 species were found in the plots, including three exotic species, Rumex acetosella, Poa pratensis, and Achillea millefolium. Vegetation was relatively sparse as indicated by the high values for bare ground and litter (25\%). A total of 102 species were observed in the dry-mesic sand prairie resulting in a FQI of 37.77 and a mean $\mathrm{CC}$ of 3.74 .

Mesic Sand Prairie: One high-quality mesic to wet-mesic sand prairie occurred on the GRSWA (SW1/4 S17 T19N R9E; Fig. 2). This extensive area of approximately 34 ha in size had high species diversity and contained few exotic species. Topographic differences were responsible for the mosaic of sand species that existed here, varying from the dry-mesic sand prairies on the low dune ridges to sand 
Table 1. Frequency (\%), mean cover (\% of total cover), and importance value (IV) of the ground layer species (with IVs >2.0) encountered in late summer of 2006 in a dry sand prairie, a dry-mesic sand prairie, and a mesic sand prairie, Green River State Wildlife Area, Lee County, Illinois. $(n=50)$ (*exotic species)

\begin{tabular}{|c|c|c|c|c|c|c|c|c|c|}
\hline \multirow[b]{3}{*}{ Species } & \multicolumn{3}{|c|}{ Dry Sand Prairie } & \multicolumn{3}{|c|}{ Dry-mesic Sand Prairie } & \multicolumn{3}{|c|}{ Mesic Sand Prairie } \\
\hline & Freq. & Mean & & Freq. & Mean & & Freq. & Mean & \\
\hline & $\%$ & Cover & IV & $\%$ & Cover & IV & $\%$ & Cover & IV \\
\hline Schizachyrium scoparium & 100 & 26.00 & 48.7 & 96 & 6.32 & 15.1 & 2 & 0.06 & 0.1 \\
\hline Ambrosia psilostachya & 100 & 10.58 & 25.2 & -- & -- & -- & -- & -- & -- \\
\hline Amorpha canescens & 64 & 5.91 & 14.8 & -- & -- & -- & -- & -- & -- \\
\hline Chrysopsis camporum & 38 & 4.61 & 10.5 & -- & -- & -- & -- & -- & -- \\
\hline Solidago nemoralis & 48 & 3.59 & 9.9 & 14 & 0.17 & 1.1 & 10 & 0.25 & 0.8 \\
\hline Coreopsis lanceolata & 54 & 3.14 & 9.7 & -- & -- & -- & -- & -- & -- \\
\hline Cyperus lupulinus & 86 & 0.53 & 8.7 & 44 & 0.27 & 3.2 & -- & -- & -- \\
\hline Rosa carolina & 46 & 1.75 & 6.9 & 28 & 0.93 & 3.1 & -- & -- & -- \\
\hline *Achillea millefolium & 60 & 0.45 & 6.2 & 22 & 0.21 & 1.7 & 50 & 0.75 & 3.6 \\
\hline Koeleria macrantha & 46 & 0.53 & 5.0 & -- & -- & -- & -- & -- & -- \\
\hline Tephrosia virginiana & 14 & 2.31 & 4.8 & -- & -- & -- & -- & -- & -- \\
\hline Dichanthelium villosissimum & 44 & 0.47 & 4.7 & 88 & 1.28 & 7.3 & -- & -- & -- \\
\hline Leptoloma cognatum & 42 & 0.41 & 4.4 & 52 & 1.00 & 4.7 & -- & -- & -- \\
\hline Liatris aspera & 22 & 0.89 & 3.4 & 100 & 8.80 & 18.9 & -- & -- & -- \\
\hline Polygala polygama & 32 & 0.16 & 3.1 & 100 & 0.55 & 7.0 & -- & -- & -- \\
\hline Asclepias verticillata & 30 & 0.15 & 2.9 & 4 & 0.02 & 0.3 & -- & -- & -- \\
\hline *Poa pratensis & 30 & 0.15 & 2.9 & 38 & 0.19 & 2.7 & 46 & 2.61 & 4.5 \\
\hline Rhus aromatica & 10 & 1.02 & 2.5 & -- & -- & -- & -- & -- & -- \\
\hline *Rumex acetosella & 24 & 0.12 & 2.4 & 62 & 0.76 & 5.0 & -- & -- & -- \\
\hline Dichanthelium oligosanthes & 16 & 0.08 & 1.6 & 80 & 0.75 & 6.1 & -- & -- & -- \\
\hline Sorghastrum nutans & 6 & 0.03 & 0.5 & 98 & 8.32 & 18.1 & 100 & 28.22 & 23.7 \\
\hline Antennaria plantaginifolia & 2 & 0.06 & 0.3 & 88 & 16.45 & 29.2 & 6 & 0.08 & 0.4 \\
\hline Lespedeza capitata & 2 & 0.06 & 0.3 & 74 & 2.34 & 8.0 & 4 & 0.02 & 0.3 \\
\hline Euphorbia corollata & 2 & 0.01 & 0.2 & 96 & 5.26 & 13.6 & -- & -- & -- \\
\hline Euthamia gymnospermoides & 2 & 0.01 & 0.0 & 196 & 7.54 & 16.9 & 100 & 7.56 & 11.0 \\
\hline Carex tonsa & -- & -- & -- & 100 & 1.70 & 8.7 & -- & -- & -- \\
\hline Rubus flagellaris & -- & -- & -- & 56 & 2.63 & 7.3 & 22 & 2.00 & 2.6 \\
\hline Dichanthelium perlongum & -- & -- & -- & 66 & 1.42 & 6.2 & -- & -- & -- \\
\hline Aristida basiramea & -- & -- & -- & 62 & 0.31 & 4.4 & -- & -- & -- \\
\hline Andropogon gerardii & -- & -- & -- & 14 & 0.85 & 2.1 & 70 & 6.39 & 8.4 \\
\hline Agrostis gigantea & -- & -- & -- & 14 & 0.07 & 1.0 & 54 & 3.69 & 5.7 \\
\hline Parthenium integrifolium & -- & -- & -- & 8 & 0.36 & 1.0 & 100 & 34.31 & 27.5 \\
\hline Viola sagittata & -- & -- & -- & 4 & 0.31 & 0.8 & 98 & 7.05 & 10.5 \\
\hline Fragaria virginiana & -- & -- & -- & -- & -- & -- & 100 & 16.63 & 16.6 \\
\hline Liatris pycnostachya & -- & -- & -- & -- & -- & -- & 98 & 13.04 & 14.2 \\
\hline Dichanthelium acuminatum & -- & -- & -- & -- & -- & -- & 98 & 8.50 & 11.4 \\
\hline Desmodium illinoense & -- & -- & -- & -- & -- & -- & 94 & 8.62 & 11.2 \\
\hline Rudbeckia subtomentosa & -- & -- & -- & -- & -- & -- & 68 & 6.47 & 8.3 \\
\hline Antennaria neglecta & -- & -- & -- & -- & -- & -- & 44 & 6.59 & 6.9 \\
\hline Panicum virgatum & -- & -- & -- & -- & -- & -- & 46 & 3.00 & 4.8 \\
\hline Acalypha gracilens & -- & -- & -- & -- & -- & -- & 64 & 0.61 & 4.4 \\
\hline Polygala sanguinea & -- & -- & -- & -- & -- & -- & 60 & 0.30 & 4.0 \\
\hline Hypericum punctatum & -- & -- & -- & -- & -- & -- & 50 & 0.55 & 3.4 \\
\hline Solidago canadensis & -- & -- & -- & -- & -- & -- & 32 & 1.38 & 2.9 \\
\hline Others & -- & 2.76 & 20.4 & -- & 0.55 & 6.5 & -- & 3.05 & 12.8 \\
\hline Totals & & 65.77 & 200.0 & & 69.36 & 200.0 & & 161.73 & 200.0 \\
\hline Bare ground and litter & & 28.71 & & & 25.35 & & & 13.03 & \\
\hline
\end{tabular}


Table 2. Similarity Index of the sand prairies and sedge meadows at the GRSWA.

\begin{tabular}{l|ccccc}
\hline \multicolumn{1}{c|}{ Communities } & $\begin{array}{c}\text { Dry Sand } \\
\text { Prairie }\end{array}$ & $\begin{array}{c}\text { Dry-mesic } \\
\text { Sand Prairie }\end{array}$ & $\begin{array}{c}\text { Mesic Sand } \\
\text { Prairie }\end{array}$ & $\begin{array}{c}\text { Wet Sand } \\
\text { Prairie }\end{array}$ & $\begin{array}{c}\text { Sedge } \\
\text { Meadow (1) }\end{array}$ \\
\hline Dry-mesic Sand Prairie & 58.82 & & & & \\
Mesic Sand Prairie & 26.09 & 49.38 & & & \\
Wet Sand Prairie & 10.34 & 11.43 & 25.00 & & \\
Sedge Meadow (1) & 00.00 & 00.00 & 00.00 & 27.96 & \\
Sedge Meadow (2) & 00.00 & 3.03 & 5.49 & 22.68 & 18.52
\end{tabular}

ponds in the small depressions. Mesic sand prairie vegetation occurred on the slopes of the dunes where the soils were comprised of Dakota sandy loam. In contrast, the wet-mesic prairie was on the lower ground between the dunes on Hoopeston fine sandy loam. Sorghastrum nutans and Andropogon gerardii were the dominant tall grasses, commonly being more than $1.6 \mathrm{~m}$ tall. Other common grasses included Dichanthelium acuminatum, Agrostis gigantea, and Panicum virgatum (Table 1). The important native forbs included Parthenium integrifolium, Fragaria virginiana, Liatris pycnostachya, Desmodium illinoense, and Euthamia gymnospermoides (Table 1). Based on the Sorensen Index of Similarity, the mesic sand prairie was similar to the dry mesic sand prairies, and has very low similarity to the wet sand prairie and sedge meadows (Table 2). A total of 44 taxa were encountered in the plots, including 3 exotic species. Bare ground and litter averaged $13 \%$. A total of 124 species were observed in the mesic prairie resulting in a FQI of 45.21 and a mean CC of 4.06 .

Wet Sand Prairie: A 5-ha wet sand prairie was located along the western and northern edges of a sedge meadow at the southeastern part of the GRSWA (NE1/4 SW1/4 S17 T19N R9E; Fig. 2). The vegetation of this prairie was transitional between the sedge meadow and wet-mesic to mesic sand prairie to the north and west. Here, changes in species composition occurred depending upon slight differences in elevation. Spartina pectinatus was the dominant grass, while Carex haydenii was the most important sedge. Common forbs included Helianthus grosseserratus, Solidago canadensis, Onoclea sensibils, Galium obtusum, Hypericum spha- erocarpum, and Silphium integrifolium all with IVs of 8.0 or higher (Table 3 ). Based on the Sorensen Index of Similarity, the wet sand prairie was similar to the mesic sand prairies and the sedge meadows, with low similarity to the drier sand communities (Table 2). Within the wet prairie 68 taxa were encountered, including three exotic species, Poa pratensis being the most important. Bare ground and litter averaged less than $2 \%$. A total of 102 species were observed in the wet sand prairie for an FQI of 39.11 and a mean CC of 3.87 .

Sedge Meadows: Hummocks were present throughout the sedge meadows, their height dependent on the distance from the sedge meadow center, i.e., smaller hummocks near the edge, larger and taller hummocks near the center. One small sedge meadow, covering less than 0.5 ha, occurred in a shallow depression near the southeast corner of GRSWA (NE1/4 SW1/4 S17 T19N R9E; Fig. 2) (sedge meadow East). Bolboschoenus fluvatilis was the most important species, followed by Carex haydenii. The common species recorded for this sedge meadow included Thelypteris palustris,

Onoclea sensibilis, and Aster praealtus. At the south edge of this sedge meadow was a depression that likely represents an old sand pond that became partially filled and no longer holds water year around. Bolboschoenus fluviatalis dominated this depression, with Persicaria amphibium also common. A total of 44 species were observed in this sedge meadow, yielding a FQI of 30.30 and a mean CC of 4.57.

A 1.5-ha sedge meadow was located at the southeast corner of the marsh (SE1/4 NE1/4 S13 T19N R8E; Fig. 2) (sedge meadow West). In 2002 this sedge meadow was dominated by 
Table 3. Frequency (\%), mean cover (\% of total cover), and importance value (IV) of the ground layer species (with IVs >2.0) encountered in late summer of 2006 in a wet sand prairie and an adjacent sedge meadow (sedge meadow East), Green River State Wildlife Area, Lee County, Illinois. $(\mathrm{n}=$ 50) (*exotic species)

\begin{tabular}{|c|c|c|c|c|c|c|}
\hline \multirow[b]{2}{*}{ Species } & \multicolumn{3}{|c|}{ Wet Sand Prairie } & \multicolumn{3}{|c|}{ Sedge Meadow East } \\
\hline & Freq. $\%$ & $\begin{array}{c}\text { Mean } \\
\text { Cover }\end{array}$ & IV & Freq. $\%$ & $\begin{array}{l}\text { Mean } \\
\text { Cover }\end{array}$ & IV \\
\hline Spartina pectinata & 50 & 23.75 & 18.8 & -- & -- & -- \\
\hline Helianthus grosseserratus & 96 & 13.57 & 14.9 & -- & -- & -- \\
\hline Solidago canadensis & 72 & 15.03 & 14.3 & -- & -- & -- \\
\hline Carex haydenii & 100 & 8.23 & 11.6 & 52 & 36.21 & 38.9 \\
\hline Onoclea sensibilis & 66 & 8.46 & 9.6 & 66 & 7.01 & 16.5 \\
\hline Galium obtusum & 82 & 4.95 & 8.3 & 2 & 0.01 & 0.3 \\
\hline Hypericum sphaerocarpum & 78 & 5.15 & 8.3 & -- & -- & -- \\
\hline Silphium integrifolium & 48 & 7.59 & 8.0 & -- & -- & -- \\
\hline Viola pratincola & 64 & 5.90 & 7.9 & -- & -- & -- \\
\hline Stachys pilosa & 92 & 2.62 & 7.4 & -- & -- & -- \\
\hline Thalictrum dasycarpum & 52 & 6.12 & 7.2 & -- & -- & -- \\
\hline Euthamia gymnospermoides & 42 & 5.10 & 5.9 & -- & -- & -- \\
\hline Rudbeckia subtomentosa & 38 & 5.19 & 5.8 & -- & -- & -- \\
\hline Solidago gigantea & 56 & 2.96 & 5.4 & -- & -- & -- \\
\hline Aster praealtus & 44 & 3.81 & 5.2 & 48 & 5.71 & 12.6 \\
\hline Pycnanthemum virginianum & 42 & 3.46 & 4.9 & -- & - & - \\
\hline Cirsium discolor & 38 & 3.20 & 4.5 & -- & -- & -- \\
\hline Comandra umbellata & 26 & 3.90 & 4.2 & -- & -- & -- \\
\hline Calystegia sepium & 38 & 2.29 & 3.9 & -- & -- & -- \\
\hline Thelypteris palustris & 24 & 3.31 & 3.7 & 50 & 13.85 & 19.8 \\
\hline Calamagrostis canadensis & 40 & 1.71 & 3.6 & -- & -- & -- \\
\hline Rubus pensilvanicus & 30 & 1.62 & 3.0 & -- & -- & -- \\
\hline Campanula aparinoides & 44 & 0.32 & 2.9 & 16 & 0.08 & 2.7 \\
\hline Muhlenbergia mexicana & 32 & 1.24 & 2.8 & 6 & 0.08 & 1.1 \\
\hline Asclepias syriaca & 22 & 1.14 & 2.1 & -- & -- & -- \\
\hline Persicaria amphibium & 24 & 0.46 & 1.8 & 50 & 4.95 & 12.3 \\
\hline Bolboschoenus fluviatilis & 10 & 0.44 & 0.9 & 50 & 42.51 & 44.3 \\
\hline Lycopus uniflorus & 10 & 0.15 & 0.7 & 36 & 0.38 & 6.1 \\
\hline Verbena hastata & 2 & 0.06 & 0.1 & 42 & 0.66 & 7.4 \\
\hline Boehmeria cylindrica & 2 & 0.01 & 0.1 & 60 & 2.59 & 12.0 \\
\hline Scutellaria galericulata & -- & - & -- & 26 & 0.13 & 4.3 \\
\hline *Solanum dulcamara & -- & -- & -- & 18 & 0.82 & 3.6 \\
\hline Triadenum fraseri & -- & -- & -- & 18 & .078 & 3.5 \\
\hline *Phalaris arundinacea & -- & -- & -- & 14 & 1.23 & 3.3 \\
\hline Bidens coronata & -- & -- & -- & 14 & 0.22 & 2.5 \\
\hline Caltha palustris & -- & -- & -- & 12 & 0.26 & 2.1 \\
\hline Others & -- & 11.40 & 22.2 & -- & 1.06 & 6.7 \\
\hline Totals & & 153.14 & 200.0 & & 118.54 & 200.0 \\
\hline Bare ground and litter & & 1.50 & & & 1.88 & \\
\hline
\end{tabular}

Carex haydenii and Calamagrostis canadensis, with Persicaria coccinea also common (Table 4). Twenty-nine taxa including three exotic species were encountered in the plots: Mentha arvensis was extremely common, followed by Chenopodium album and Persicaria vulgaris. Though burned in 2005, no peat fires occurred here and the area was not subjected to disking. The three most important species in 2005 maintained their dominance during 2006 and 2007. Eleven additional species were found in the plots in 2006. By 2007 most of these species were lost or greatly reduced in abundance, and the original dominants of 2002 had regained much of their previous importance. By 2007 two native forbs, Teucrium canadense and Aster praealtus, had become more obvious (Table 4). In 2002, a total of 42 species were observed in this sedge meadow for an FQI of 21.49 and a mean $\mathrm{CC}$ of 3.31 . 
Marsh: Located along the western edge of the GRSWA, the marsh was divided into five vegetation zones (W1/2 S13 T19N R8E; Fig. 2). Within this 40 -ha marsh/sedge meadow complex the vegetation zones were mostly dependent on slight differences in elevation, soils, and past disturbance, particularly drainage attempts and fire frequency, intensity, and time of year. The transitions between the various vegetation zones were abrupt with the edges of the zones being very distinct. Of the 36 species encountered, including several conservative species, only 5 were exotics. The marsh FQI was 18.48 and the mean CC was 3.08. Much of this marsh area was burned in the fall of 2005.

Phalaris Vegetation Zone: The exotic

Phalaris arundinacea was the dominant species in shallow areas throughout the marsh where water level fluctuations were pronounced (Table 5). This disturbance community occurred in areas where water levels were usually low and flooding was of short duration. This zone was found throughout nearly all of the extensive wetlands at the GRSWA and accounted for nearly half of the marsh area. When surveyed in 2002, Phalaris arundinacea dominated, Persicaria coccinea was second, and six other species were encountered. In 2006, after the 2005 fire, $P$. arundinacea continued to dominate. Many other species were also present in 2006, but by 2007 many had disappeared (Table 5). Most notable was Ambrosia artemisiifolia, which in 2006 was second in imnportance, but was not found in the plots in 2007.

Salix interior thickets were common at the edge of the marsh as narrow bands at the base of the stabilized dunes. When surveyed in 2002, Phalaris arundinacea dominated the ground layer beneath these willow thickets; Persicaria punctatum was also common, whereas seven other species were occasionally encountered (Table 6). After the 2005 fire, $P$. arundinacea still dominated; Urtica gracilis was second in importance in 2006 but dropped to third by 2007. Five taxa not found in 2002 were encountered in 2006, and the number of new species had increased to 14 by 2007 .

An extensive Phalaris arundinacea population occurred in a shallow depression near the middle of the GRSWA and close to the office building (SW1/4 NE1/4 S18 T19N R9E). During the 2005 fire, this entire area burned and extensive peat fires destroyed much of the peat; the depression was flooded and disked in efforts to control the fires. Phalaris arundinacea was not recorded in any of the plots when the site was surveyed in 2006. Thirteen native species were present, although the exotic Circium arvense was the dominant taxon (Table 7). Other relatively important species included the native taxa Oenothera biennis, Verbena hastata, and Persicaria punctata along with the exotic Chenopodium album. By 2007 P. arundinacea had returned, Cirsium arvense had nearly disappeared and though many native weedy species had invaded, extensive areas of bare ground were present (Table 7).

Typha/Persicaria Vegetation Zone: Scattered throughout the marsh in 2002 were extensive areas of Typha latifolia (Table 8). Persicaria cooccinea and Carex lacustris were common among the cattails. Many other species were occasionally encountered, although none were very important, as indicated by low mean cover. Typha latifolia nearly disappeared following the fire, before increasing in importance in 2007 (Table 8). Phalaris arundinacea increased between 2005 and 2006, and by 2007 was the dominant species present. Fourteen additional species were recorded in these plots in 2006, whereas many had disappeared by 2007 .

One extensive Typha latifolia population of 16 ha in size occurred next to the road at the western edge of the marsh, separated from the rest of the marsh by a narrow sand ridge. During the 2005 fire, much of this area burned and the fire destroyed extensive areas of peat, the fires smoldering for a few days. The depression was intentionally flooded and disked. Though the dominant species before the 2005 fire, $T$. latifolia was uncommon in 2006, but increased significantly in 2007 (Table 9). Phalaris arundinacea, which was rarely encountered before the 2005 fire, was the dominant species in 2006 and 2007.

Bolboschoenus fluviatilis Vegetation Zone: Bolboschoenus fluviatilis was the dominant species in an area of about 1.2 ha (Table 10). Persicaria coccinea, Sparganium eurycarpum, and Urtica gracilis were common under the river bulrush. Only five species were found in the plots and no exotic species were encountered in 2002 (Table 10). After the 2005 fire, $B$. fluviatilis initially decreased and then increased in importance. Thirteen additional species were recorded in these plots in 2006, although many had disappeared by 2007. By 2007, Persicaria coccinea had recovered, Sparganium eury- 
Table 4. Frequency (\%), mean cover (\% of total cover), and importance value (IV) of the ground layer species encountered in late summer of 2002 and again in 2006 and 2007 in a sedge meadow (sedge meadow West) at the western edge of the Green River State Wildlife Area, Lee County, Illinois. ( $\mathrm{n}=50)$ (*exotic species)

\begin{tabular}{|c|c|c|c|c|c|c|c|c|c|}
\hline \multirow{3}{*}{ Species } & \multicolumn{3}{|c|}{ Summer 2002} & \multicolumn{3}{|c|}{ Summer 2006} & \multicolumn{3}{|c|}{ Summer 2007} \\
\hline & Freq. & Mean & & Freq. & Mean & & Freq. & Mean & \\
\hline & & Cover & IV & $\%$ & Cover & IV & & Cover & IV \\
\hline Carex haydenii & 100 & 30.93 & 43.7 & 100 & 43.09 & 38.9 & 96 & 43.85 & 43.9 \\
\hline Calamagrostis canadensis & 100 & 29.88 & 42.7 & 96 & 29.32 & 29.3 & 100 & 52.80 & 50.4 \\
\hline Persicaria coccinea & 52 & 17.27 & 24.0 & 34 & 9.01 & 9.4 & 56 & 16.92 & 19.8 \\
\hline *Mentha arvensis & 72 & 5.18 & 15.0 & 38 & 1.08 & 4.5 & 20 & 1.12 & 3.8 \\
\hline Eupatoriadelphus maculatus & 56 & 7.06 & 14.6 & 28 & 1.56 & 3.9 & 10 & 0.73 & 2.1 \\
\hline Persicaria punctata & 72 & 1.40 & 11.3 & 64 & 1.11 & 7.0 & 44 & 0.62 & 7.2 \\
\hline Lycopus uniflorus & 58 & 2.31 & 10.3 & 62 & 1.36 & 7.0 & 22 & 0.75 & 3.9 \\
\hline Verbena hastata & 28 & 2.04 & 5.9 & 2 & 0.01 & 0.2 & 16 & 0.23 & 2.7 \\
\hline Scutellaria galericulata & 24 & 0.76 & 4.1 & 10 & 0.10 & 1.1 & 10 & 0.15 & 1.6 \\
\hline Helianthus grosseserratus & 20 & 1.27 & 4.0 & 84 & 17.40 & 20.0 & 16 & 0.18 & 2.6 \\
\hline Teucrium canadense & 22 & 0.60 & 3.7 & 82 & 6.15 & 12.3 & 42 & 0.95 & 7.1 \\
\hline Lycopus americanus & 16 & 0.67 & 2.8 & 18 & 0.44 & 2.1 & 8 & 0.48 & 1.5 \\
\hline Polygonum ramosissimum & 14 & 0.46 & 2.5 & 40 & 2.20 & 5.5 & 20 & 0.10 & 3.2 \\
\hline Aster puniceus & 12 & 0.60 & 2.3 & 36 & 2.47 & 5.3 & 14 & 0.56 & 2.6 \\
\hline Ambrosia artemisiifolia & 10 & 0.49 & 1.9 & 50 & 11.47 & 12.6 & 10 & 0.10 & 1.6 \\
\hline Stachys pilosa & 8 & 0.48 & 1.6 & 28 & 4.62 & 5.9 & -- & -- & -- \\
\hline Rumex orbiculatus & 8 & 0.43 & 1.5 & 4 & 0.02 & 0.4 & 2 & 0.30 & 0.5 \\
\hline Asclepias incarnata & 8 & 0.14 & 1.2 & -- & -- & -- & 2 & 0.01 & 0.3 \\
\hline Galium obtusum & 6 & 0.42 & 1.2 & 4 & 0.60 & 0.8 & 2 & 0.01 & 0.3 \\
\hline Aster praealtus & 4 & 0.36 & 0.9 & 40 & 5.86 & 7.9 & 86 & 26.43 & 30.8 \\
\hline Epilobium coloratum & 4 & 0.36 & 0.9 & -- & -- & -- & -- & -- & -- \\
\hline Solidago gigantea & 4 & 0.31 & 0.9 & 50 & 6.96 & 9.6 & 8 & 0.24 & 1.4 \\
\hline Cardamine pensylvanica & 6 & 0.03 & 0.8 & 2 & 0.01 & 0.2 & 8 & 0.04 & 1.2 \\
\hline Acalypha rhomboidea & 2 & 0.06 & 0.4 & 2 & 0.01 & 0.2 & 2 & 0.01 & 0.3 \\
\hline Eleocharis verrucosa & 2 & 0.06 & 0.4 & -- & -- & -- & -- & -- & -- \\
\hline Geum laciniatum & 2 & 0.06 & 0.4 & -- & -- & -- & -- & -- & -- \\
\hline Lathyrus palustris & 2 & 0.06 & 0.4 & -- & -- & -- & 12 & 1.03 & 2.7 \\
\hline *Chenopodium album & 2 & 0.01 & 0.3 & 44 & 1.21 & 5.1 & -- & -- & -- \\
\hline *Persicaria vulgaris & 2 & 0.01 & 0.3 & -- & -- & -- & -- & -- & -- \\
\hline *Potentilla norvegica & -- & -- & -- & 38 & 0.24 & 4.0 & 4 & 0.02 & 0.6 \\
\hline Cirsium discolor & -- & -- & -- & 20 & 0.35 & 2.2 & 2 & 0.01 & 0.3 \\
\hline Solidago canadensis & -- & -- & -- & 4 & 1.50 & 1.4 & 4 & 0.07 & 0.6 \\
\hline Lactuca canadensis & -- & -- & -- & 10 & 0.10 & 1.1 & -- & -- & -- \\
\hline *Cirsium arvense & -- & -- & -- & 4 & 0.12 & 0.5 & -- & -- & -- \\
\hline Persicaria pensylvanica & -- & -- & -- & 4 & 0.02 & 0.4 & -- & -- & -- \\
\hline *Trifolium repens & -- & -- & -- & 4 & 0.02 & 0.4 & -- & -- & -- \\
\hline Hackelia virginiana & -- & -- & -- & 2 & 0.06 & 0.2 & -- & -- & -- \\
\hline Helenium autumnale & -- & -- & -- & 2 & 0.06 & 0.2 & -- & -- & -- \\
\hline Solanum ptychanthum & -- & -- & -- & 2 & 0.01 & 0.2 & -- & -- & -- \\
\hline Typha latifolia & -- & -- & -- & 2 & 0.01 & 0.2 & 16 & 0.96 & 3.1 \\
\hline *Phalaris arundinacea & -- & -- & -- & -- & -- & -- & 12 & 1.77 & 3.0 \\
\hline Eupatorium perfoliatum & -- & -- & -- & -- & -- & -- & 2 & 0.01 & 0.3 \\
\hline Iris shrevei & -- & -- & -- & -- & -- & -- & 2 & 0.01 & 0.3 \\
\hline Lysimachia thrysiflora & -- & -- & -- & -- & -- & -- & 2 & 0.06 & 0.3 \\
\hline Totals & & 103.71 & 200.0 & & 148.55 & 200.0 & & 150.52 & 200.0 \\
\hline Bare ground and litter & & 1.20 & & & 3.65 & & & 2.13 & \\
\hline
\end{tabular}


carpum was still recovering, whereas Urtica gracilis was not recorded.

Sparganium eurycarpum Vegetation Zone: A few small areas of $\leq 0.5$ ha were dominated by Sparganium euryocarpum (Table 11). Persicaria coccinea was also important followed by Urtica gracilis. Only eight species were found in the plots and the exotic Phalaris arundinacea was rarely encountered. After the 2005 fire, S. eurycarpum was absent from the plots and by 2007 was still uncommon. In contrast, Persicaria coccinea increased in important in 2006 and again in 2007. Thirteen additional species were recorded in these plots in 2006, whereas some were absent in 2007.

Carex lacustris/Persicaria coccinea Vegetation Zone: Located next to the sedge meadow in the southeastern part of the marsh, this zone covered approximately 5 to 6 ha. The dominant species, Carex lacustris, Persicaria coccinea, and Calamagrostis canadensis, far exceed the importance of the other species present (Table 12). Thirteen species were encountered in the plots with more than half having IVs of less than 1.5. Though burned in 2005, no peat fires occurred and the area was not subjected to disking. During the 2006 and 2007 surveys, the three dominant species maintained their importance. Seventeen additional species were found in the plots in 2006, including the native Ambrosia artemisiifolia and exotic Chenopodium album. By 2007 most of these species were absent or greatly reduced in abundance, and the original dominants of 2002 had regained much of their previous importance. By 2007 two native prairie forbs, Teucrium canadense and Aster praealtus, became much more abundant (Table 12).

Sand Pond: Scattered through the lowlands of the GRSWA were a few small sand ponds, none more than $55 \mathrm{~m}$ across. The vegetation surrounding these ponds varied extensively. Most ponds were located where Phalaris arundinacea dominated the pond margins with few other species being encountered. Around a few

Table 5. Frequency (\%), mean cover (\% of total cover), and importance value (IV) of the ground layer species encountered in late summer of 2002 and again in 2006 and 2007 in a Phalaris arundinacea vegetation zone that is not shaded in the marsh at the western edge of the Green River State Wildlife Area, Lee County, Illinois. $(\mathrm{n}=50)$ (*exotic species)

\begin{tabular}{|c|c|c|c|c|c|c|c|c|c|}
\hline \multirow{3}{*}{ Species } & \multicolumn{3}{|c|}{ Summer 2002} & \multicolumn{3}{|c|}{ Summer 2006} & \multicolumn{3}{|c|}{ Summer 2007} \\
\hline & Freq. & Mean & & Freq. & Mean & & Freq. & Mean & \\
\hline & $\%$ & Cover & IV & $\%$ & Cover & IV & $\%$ & Cover & IV \\
\hline *Phalaris arundinacea & 100 & 79.05 & 130.1 & 100 & 84.55 & 117.1 & 100 & 83.30 & 142.4 \\
\hline Persicaria coccinea & 80 & 8.17 & 44.3 & 66 & 7.45 & 28.5 & 60 & 7.27 & 40.2 \\
\hline Leersia oryzoides & 20 & 1.94 & 10.9 & -- & -- & -- & -- & -- & -- \\
\hline Iris shrevei & 16 & 1.63 & 8.9 & 4 & 0.07 & 1.4 & 8 & 1.41 & 5.8 \\
\hline Typha latifolia & 4 & 0.12 & 1.9 & -- & -- & -- & -- & -- & -- \\
\hline Hibiscus laevis & 2 & 0.75 & 1.7 & -- & -- & -- & -- & -- & -- \\
\hline Sium suave & 2 & 0.30 & 1.2 & -- & -- & -- & -- & -- & -- \\
\hline *Cirsium arvense & 2 & 0.06 & 1.0 & 4 & 0.02 & 1.3 & -- & -- & -- \\
\hline Ambrosia artemisiifolia & -- & -- & -- & 84 & 4.99 & 31.8 & -- & -- & -- \\
\hline Rubus pensilvanicus & -- & -- & -- & 12 & 1.56 & 5.4 & 10 & 1.95 & 7.5 \\
\hline Scirpus cyperinus & -- & -- & -- & 6 & 0.08 & 2.0 & -- & -- & -- \\
\hline Persicaria punctata & -- & -- & -- & 6 & 0.03 & 1.9 & 2 & 0.01 & 1.1 \\
\hline *Sida spinosa & -- & -- & -- & 6 & 0.03 & 1.9 & -- & -- & -- \\
\hline Stachys pilosa & -- & -- & -- & 4 & 0.07 & 1.4 & -- & -- & -- \\
\hline Teucrium canadense & -- & -- & -- & 4 & 0.12 & 1.4 & -- & -- & -- \\
\hline Verbena hastata & -- & -- & -- & 4 & 0.02 & 1.3 & -- & -- & -- \\
\hline Calamgrostis canadensis & -- & -- & -- & 2 & 0.30 & 0.9 & 2 & 0.75 & 1.9 \\
\hline Ambrosia trifida & -- & -- & -- & 2 & 0.06 & 0.7 & -- & -- & -- \\
\hline Carex lacustris & -- & -- & -- & 2 & 0.01 & 0.6 & 2 & 0.01 & 1.1 \\
\hline Hackelia virginiana & -- & -- & -- & 2 & 0.01 & 0.6 & -- & -- & -- \\
\hline Solanum ptychanthum & -- & -- & -- & 2 & 0.01 & 0.6 & -- & -- & -- \\
\hline *Verbascum thapsus & -- & -- & -- & 2 & 0.01 & 0.6 & -- & -- & -- \\
\hline Vitis riparia & -- & -- & -- & 2 & 0.01 & 0.6 & -- & -- & -- \\
\hline Totals & & 92.02 & 200.0 & & 99.40 & 200.0 & & 94.70 & 200.0 \\
\hline Bare ground and litter & & 10.61 & & & 5.76 & & & 6.08 & \\
\hline
\end{tabular}


ponds, however, wet to wet-mesic sand prairie vegetation dominated depending on the steepness of the shoreline. No high-quality sand ponds were encountered during this study.

Sand Forest: Both lowland and upland forests were located at GRSWA (Fig. 2). The lowland forests were dominated by Acer saccharinum with a few subdominant species including Prunus serotina, Populus deltoides, Juglans nigra, Acer negundo, Salix nigra, and Fraxinus pennsylvanica (Sites 1, 2, 3, and 4, Table 13). In these forests Acer saccharinum was consistently of highest importance, highest density, and of relatively large size. In contrast, the upland forests where commonly dominated by Prunus serotina along with the exotic species Morus alba or Robinia pseudoacacia and some of the lowland forest species (Sites 5 and 6 , Table 13). In both forest types the woody understory was dense, with many native and exotic trees and shrubs common. Overall, woody seedling densities averaged between 6,000 and 16,000 stems/ha, small saplings averaged between 3,200 and 6,850 stems/ha, while large saplings were not common with an average between 0 and 740 stems/ha. The most abundant understory shrubs were mostly exotic species with Elaeagnus umbellata, Lonicera maackii, Lonicera $x$ bella, Rhamnus cathartica, and Rosa multiflora common.

The ground layer in these six forest sites was similar. In addition to the numerous woody tree seedlings and shrub in the ground layer, many herbaceous species were common. Generally native herbs dominated, with Ageratina altissima, Antenoron virginianum, Boehmeria cylindrica, Cryptotaenia canadensis, Geum canadense, Osmorhiza sp., Phytolacca americana, Solidago canadensis, and $S$. gigantea being the most common taxa. A few exotic herbs such as Alliaria petiolata, Bromus inermis, Fallopia convolvulus,

Table 6. Frequency (\%), mean cover (\% of total cover), and importance value (IV) of the ground layer species encountered in late summer of 2002 and again in 2006 and 2007 in a Phalaris arundinacea vegetation zone community that is shaded under a thicket of Salix interior in the marsh at the western edge of the Green River State Wildlife Area, Lee County, Illinois. $(n=50)$. (*exotic species)

\begin{tabular}{|c|c|c|c|c|c|c|c|c|c|}
\hline \multirow[b]{2}{*}{ Species } & \multicolumn{3}{|c|}{ Summer 2002} & \multicolumn{3}{|c|}{ Summer 2006} & \multicolumn{3}{|c|}{ Summer 2007} \\
\hline & Freq. & Mean & IV & Freq. & Mean & IV & Freq. & Mean & IV \\
\hline *Phalaris arundinacea & 100 & 59.10 & 146.3 & 100 & 73.77 & 136.9 & 100 & 48.05 & 97.2 \\
\hline Persicaria punctata & 48 & 1.24 & 26.5 & 14 & 1.38 & 9.3 & 50 & 6.56 & 23.4 \\
\hline Urtica gracilis & 14 & 0.12 & 7.3 & 38 & 7.71 & 29.6 & 42 & 3.24 & 16.4 \\
\hline Persicaria coccinea & 10 & 0.78 & 6.4 & -- & -- & -- & 2 & 0.30 & 1.0 \\
\hline Carex lacustris & 10 & 0.54 & 6.0 & -- & -- & -- & -- & -- & -- \\
\hline Scutellaria lateriflora & 6 & 0.13 & 3.3 & -- & -- & -- & -- & -- & -- \\
\hline Pilea pumila & 4 & 0.02 & 2.1 & -- & -- & -- & 24 & 2.51 & 10.3 \\
\hline Vitis riparia & 2 & 0.06 & 1.1 & -- & -- & -- & 2 & 0.06 & 0.7 \\
\hline Phytolacca americana & 2 & 0.01 & 1.0 & 4 & 1.05 & 3.4 & 6 & 0.08 & 1.8 \\
\hline Fallopia scandens & -- & -- & -- & 16 & 6.05 & 15.6 & 12 & 2.01 & 6.2 \\
\hline Persicaria pensylvanica & -- & -- & -- & 2 & 0.30 & 1.4 & 40 & 3.07 & 15.4 \\
\hline Rubus occidentalis & -- & -- & -- & 2 & 0.30 & 1.4 & -- & -- & -- \\
\hline *Silene pratensis & -- & -- & -- & 2 & 0.06 & 1.2 & -- & -- & -- \\
\hline Solanum ptychanthum & -- & -- & -- & 2 & 0.06 & 1.2 & 6 & 0.03 & 1.8 \\
\hline Lemna minor & -- & -- & -- & -- & -- & -- & 32 & 1.34 & 10.9 \\
\hline Salix nigra & -- & -- & -- & -- & -- & -- & 10 & 0.34 & 3.3 \\
\hline *Alliaria petiolata & -- & -- & -- & -- & -- & -- & 8 & 0.67 & 3.2 \\
\hline Boehmeria cylindrica & -- & -- & -- & -- & -- & -- & 8 & 0.14 & 2.4 \\
\hline Cuscuta gronovii & -- & -- & -- & -- & -- & -- & 4 & 0.07 & 1.1 \\
\hline Rorippa palustris & -- & -- & -- & -- & -- & -- & 4 & 0.07 & 1.1 \\
\hline Aster puniceus & -- & -- & -- & -- & -- & -- & 2 & 0.30 & 1.0 \\
\hline Typha latifolia & -- & -- & -- & -- & -- & -- & 2 & 0.30 & 1.0 \\
\hline Cirsium discolor & -- & -- & -- & -- & -- & -- & 2 & 0.01 & 0.6 \\
\hline Geum canadense & -- & -- & -- & -- & -- & -- & 2 & 0.01 & 0.6 \\
\hline *Persicaria vulgaris & -- & -- & -- & -- & -- & -- & 2 & 0.01 & 0.6 \\
\hline Totals & & 62.00 & 200.0 & & 90.68 & 200.0 & & 69.17 & 200.0 \\
\hline Bare ground and litter & & 34.02 & & & 4.42 & & & 34.20 & \\
\hline
\end{tabular}


and Phalaris arundinacea sometimes dominated.

Woody encroachment at the GRSWA had increased dramatically, based on the analysis of aerial photographs. In 1939, one year after the initial purchase of the land for the GRSWA, approximately 47.5 ha ( $4.6 \%$ cover) were covered by trees and large shrubs. The extent of the forested areas had increased to 72.2 ha (7\% cover) by $1951,184.9$ ha ( $17.8 \%$ cover) in 1970 , and 294.6 ha (29.4\% cover) in 1988. Woody encroachment was most obvious along many of the original hedge rows and where pine plantations were introduced soon after the site was purchased.

In 2001 most of the forests at the GRSWA were clear-cut. Two of these resulting successional areas, a lowland and an upland site, were surveyed in 2002, 2003, and 2006. Of 47 taxa recorded in 2002, Phalaris arundinacea and Persicaria pensylvanica dominated the lowland site (Table 14). In 2003, P. arundinacea continued to dominate with Persicaria pensylvanica, Conyza canadensis, Potentilla norvegica, and Populus deltoids seedlings important. Phalaris arundinacea dominated during the 2006 survey, whereas Solidago canadensis, Persicaria pensylvanica, Lactuca serriola, and Chenopodium album were among the most important of 58 species encountered (Table 14). Throughout the survey, P. arundinacea and Persicaria pensylvanica remained dominant members of the lowland community. Overall, 17 species were recorded in all 3 years of the study, with 23 taxa restricted to 2006, 20 found only in 2003, and 15 restricted to 2002; 28 exotic species were recorded in the lowland plots .

Table 7. Frequency (\%), mean cover (\% of total cover), and importance value (IV) of the ground layer species encountered in late summer of 2006 and 2007 in a marsh that had been dominated by Phalaris arundinacea prior to a fire in late 2005, Green River State Wildlife Area, Lee County, Illinois. $(\mathrm{n}=50)$ (*exotic species)

\begin{tabular}{|c|c|c|c|c|c|c|}
\hline \multirow{3}{*}{ Species } & \multicolumn{3}{|c|}{ Summer 2006} & \multicolumn{3}{|c|}{ Summer 2007} \\
\hline & Freq. & Mean & & Freq. & Mean & \\
\hline & $\%$ & Cover & IV & $\%$ & Cover & IV \\
\hline *Cirsium arvense & 100 & 63.00 & 123.8 & 2 & 0.01 & 0.9 \\
\hline Oenothera biennis & 20 & 3.45 & 13.5 & -- & -- & -- \\
\hline *Chenopodium album & 20 & 3.00 & 12.9 & -- & -- & -- \\
\hline Verbena hastata & 18 & 2.41 & 11.2 & -- & -- & -- \\
\hline Persicaria punctata & 16 & 2.85 & 10.8 & 78 & 11.93 & 91.0 \\
\hline Amaranthus tuberculatus & 12 & 2.70 & 8.8 & -- & -- & -- \\
\hline Cycloloma atriplicifolium & 8 & 0.96 & 4.9 & -- & -- & -- \\
\hline Calamagrostis canadensis & 6 & 0.90 & 3.9 & 14 & 4.74 & 28.8 \\
\hline Solanum ptychanthum & 6 & 0.03 & 2.8 & -- & -- & -- \\
\hline Ambrosia artemisiifolia & 2 & 0.30 & 1.3 & -- & -- & -- \\
\hline Aster praealtus & 2 & 0.30 & 1.3 & 22 & 0.50 & 12.0 \\
\hline Euthamia graminifolia & 2 & 0.30 & 1.3 & -- & -- & -- \\
\hline Persicaria pensylvanica & 2 & 0.30 & 1.3 & 40 & 1.33 & 23.8 \\
\hline Solidago canadensis & 2 & 0.30 & 1.3 & -- & -- & -- \\
\hline Carex haydenii & 2 & 0.06 & 0.9 & -- & -- & -- \\
\hline *Phalaris arundinacea & -- & -- & -- & 8 & 1.33 & 9.9 \\
\hline Persicaria lapathifolia & -- & -- & -- & 6 & 0.18 & 3.5 \\
\hline Typha latifolia & -- & -- & -- & 14 & 0.17 & 6.9 \\
\hline Salix nigra & -- & -- & -- & 12 & 0.06 & 5.5 \\
\hline Carex lacustris & -- & -- & -- & 6 & 0.42 & 4.6 \\
\hline *Mentha arvensis & -- & -- & -- & 6 & 0.03 & 2.7 \\
\hline Persicaria amphibium & -- & -- & -- & 4 & 0.07 & 2.0 \\
\hline Cardamine pensylvanica & -- & -- & -- & 4 & 0.02 & 1.8 \\
\hline *Persicaria vulgaris & -- & -- & -- & 4 & 0.02 & 1.8 \\
\hline Salix interior & -- & -- & -- & 4 & 0.02 & 1.8 \\
\hline *Setaria faberi & -- & -- & -- & 2 & 0.06 & 1.2 \\
\hline Populus deltoides & -- & -- & -- & 2 & 0.01 & 0.9 \\
\hline *Potentilla norvegica & -- & -- & -- & 2 & 0.01 & 0.9 \\
\hline Totals & & 80.86 & 200.0 & & 20.91 & 200.0 \\
\hline Bare ground and litter & & 22.12 & & & 71.52 & \\
\hline
\end{tabular}


In 2002 Phytolacca americana dominated the upland site, with Solanum ptychanthum, Chenopodium album, Lonicera maackii, and Cyperus schweinitzii following in importance (Table 15). By 2003 Conyza canadensis dominated, followed by Lonicera maackii, Verbascum thapsus, and Cyperus lupulinus. In 2006 Rubus pensilvanicus, Verbascum thapsus, Chenopodium album, and Lonicera maackii were the important taxa. The number of taxa recorded in the plots varied from 41 to 48 , including 21 exotic species.

\section{DISCUSSION}

Exotic Species: The sand prairie communities at the GRSWA had high species richness, many prairie conservative species, and few exotic taxa. Exotic species were usually present in low numbers, occurred in restricted areas, and were not major community components. Only three exotic species were consistently encountered in the plots of the upland sand prairies. These species, Achillea millefolium, Rumex acetosella and Poa pratensis, were mostly localized, and though sometimes recorded in high frequencies, they had low densities. In the wet sand prairie

Table 8. Frequency (\%), mean cover (\% of total cover), and importance value (IV) of the ground layer species encountered in late summer of 2002 and again in 2006 and 2007 in a Typha latifolia vegetation zone in the marsh at the western edge of the Green River State Wildlife Area, Lee County, Illinois. ( $\mathrm{n}=50)$ (*exotic species)

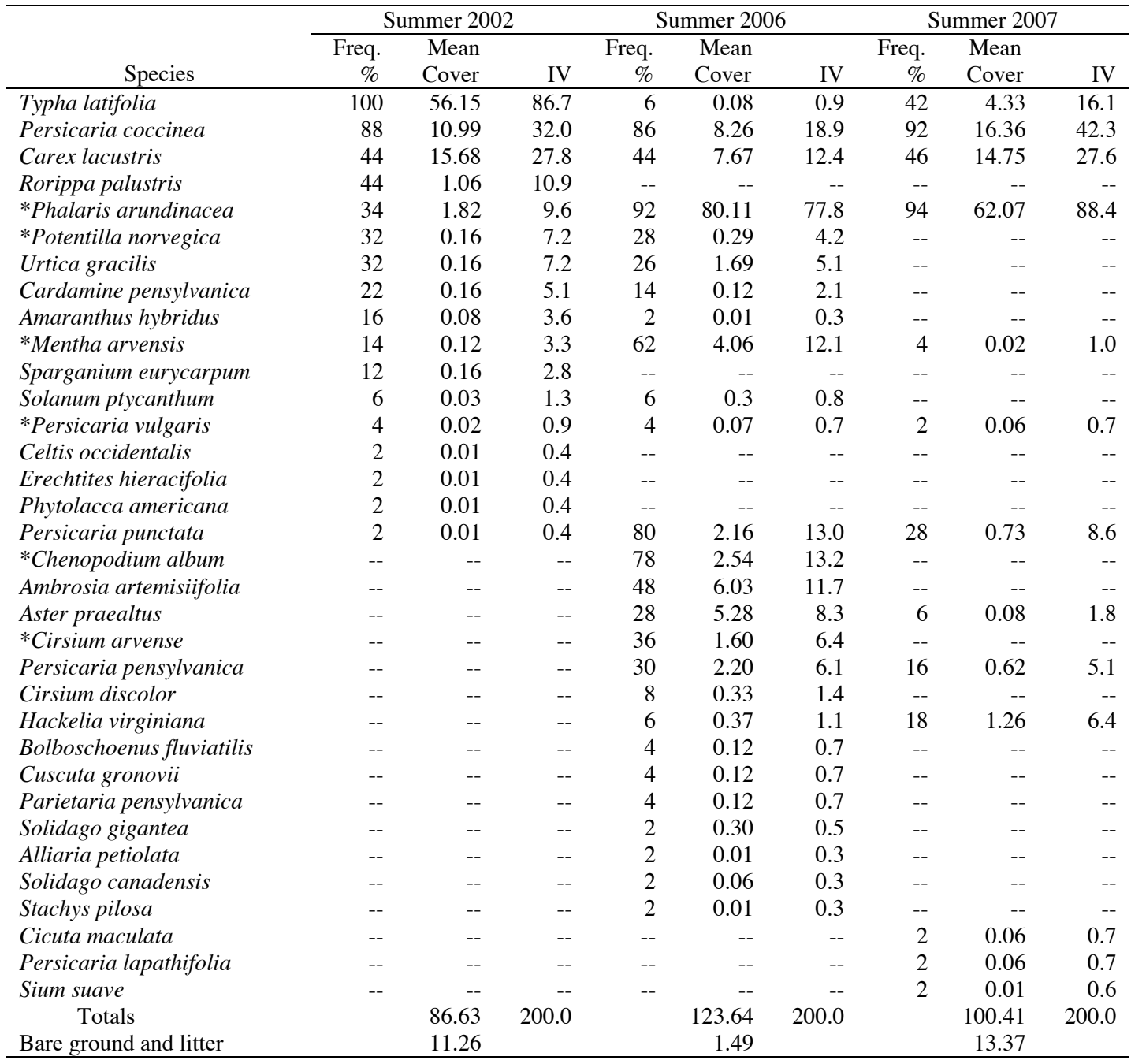


Table 9. Frequency (\%), mean cover (\% of total cover), and importance value (IV) of the ground layer species encountered in late summer of 2006 and 2007 in a marsh area that had been dominated by Typha latifolia prior to a fire in late 2005, Green River State Wildlife Area, Lee County, Illinois. $(\mathrm{n}=50)$ (*exotic species)

\begin{tabular}{|c|c|c|c|c|c|c|}
\hline \multirow[t]{2}{*}{ Species } & \multicolumn{3}{|c|}{ Summer 2006} & \multicolumn{3}{|c|}{ Summer 2007} \\
\hline & $\begin{array}{r}\text { Freq. } \\
\%\end{array}$ & $\begin{array}{l}\text { Mean } \\
\text { Cover }\end{array}$ & IV & $\begin{array}{r}\text { Freq. } \\
\% \\
\end{array}$ & $\begin{array}{l}\text { Mean } \\
\text { Cover }\end{array}$ & IV \\
\hline *Phalaris arundinacea & 100 & 80.25 & 132.5 & 92 & 18.27 & 65.5 \\
\hline Persicaria pensylvanica & 40 & 7.31 & 26.8 & 32 & 0.78 & 9.8 \\
\hline Persicaria punctata & 38 & 3.78 & 22.1 & 76 & 4.66 & 29.8 \\
\hline *Cirsium arvense & 8 & 0.96 & 4.8 & -- & -- & -- \\
\hline Ambrosia artemisiifolia & 8 & 0.72 & 4.6 & -- & -- & -- \\
\hline Typha latifolia & 8 & 0.72 & 4.6 & 58 & 11.64 & 41.6 \\
\hline Cuscuta gronvii & 4 & 0.36 & 2.3 & -- & -- & -- \\
\hline Persicaria lapathifolia & 4 & 0.36 & 2.3 & 8 & 0.04 & 2.1 \\
\hline Bolboschoenus fluviatilis & -- & -- & -- & 24 & 5.48 & 18.7 \\
\hline Lemna minor & -- & -- & -- & 60 & 0.30 & 15.7 \\
\hline Persicaria amphibium & -- & -- & -- & 40 & 0.49 & 11.1 \\
\hline Typha angustifolia & -- & -- & -- & 4 & 1.05 & 3.5 \\
\hline Schoenoplectus tabernaemontani & -- & -- & -- & 2 & 0.30 & 1.2 \\
\hline Cardamine pensylvanica & -- & -- & -- & 2 & 0.01 & 0.5 \\
\hline *Mentha arvensis & -- & -- & -- & 2 & 0.01 & 0.5 \\
\hline Totals & & 94.46 & 200.0 & & 43.03 & 200.0 \\
\hline Bare ground and litter & & 6.97 & & & 47.55 & \\
\hline
\end{tabular}

Table 10. Frequency (\%), mean cover (\% of total cover), and importance value (IV) of the ground layer species encountered in late summer of 2002 and again in 2006 and 2007 in a Bolboschoenus fluviatilis vegetation zone in the marsh at the western edge of the Green River State Wildlife Area, Lee County, Illinois. (n=50) (*exotic species)

\begin{tabular}{|c|c|c|c|c|c|c|c|c|c|}
\hline \multirow{3}{*}{ Species } & \multicolumn{3}{|c|}{ Summer 2002} & \multicolumn{3}{|c|}{ Summer 2006} & \multicolumn{3}{|c|}{ Summer 2007} \\
\hline & Freq. & Mean & & Freq. & Mean & & Freq. & Mean & \\
\hline & $\%$ & Cover & IV & $\%$ & Cover & IV & $\%$ & Cover & IV \\
\hline Bolboschoenus fluviatilis & 100 & 69.15 & 109.7 & 6 & 0.42 & 1.5 & 100 & 43.95 & 68.0 \\
\hline Persicaria coccinea & 98 & 14.91 & 47.0 & 68 & 12.85 & 24.6 & 98 & 26.40 & 50.0 \\
\hline Sparganium eurycarpum & 62 & 2.18 & 21.4 & -- & -- & -- & 26 & 1.11 & 7.4 \\
\hline Urtica gracilis & 66 & 1.08 & 21.3 & 42 & 17.02 & 23.4 & -- & -- & -- \\
\hline Rorippa palustris & 2 & 0.01 & 0.6 & 4 & 0.02 & 0.8 & -- & -- & -- \\
\hline *Persicaria vulgaris & -- & -- & -- & 68 & 29.04 & 39.3 & 2 & 0.01 & 0.5 \\
\hline *Chenopodium album & -- & -- & -- & 90 & 5.25 & 21.8 & -- & -- & -- \\
\hline Persicaria pensylvanica & -- & -- & -- & 34 & 13.86 & 19.0 & 70 & 4.01 & 21.0 \\
\hline Cuscuta gronovii & -- & -- & -- & 62 & 6.27 & 17.4 & -- & -- & -- \\
\hline Persicaria punctata & -- & -- & -- & 60 & 6.04 & 16.9 & 92 & 18.76 & 40.9 \\
\hline *Mentha arvensis & -- & -- & -- & 40 & 9.91 & 16.6 & -- & -- & -- \\
\hline Persicaria lapathifolia & -- & -- & -- & 12 & 4.41 & 6.3 & -- & -- & -- \\
\hline Ambrosia artemisiifolia & -- & -- & -- & 18 & 2.70 & 5.9 & -- & -- & -- \\
\hline *Phalaris arundinacea & -- & -- & -- & 10 & 1.23 & 3.0 & 14 & 6.30 & 9.7 \\
\hline Amaranthus tuberculatus & -- & -- & -- & 6 & 0.42 & 1.5 & -- & -- & -- \\
\hline Erechtites hieracifolia & -- & -- & -- & 4 & 0.12 & 0.8 & -- & -- & -- \\
\hline Aster praealtus & -- & -- & -- & 2 & 0.30 & 0.7 & -- & -- & -- \\
\hline Cirsium discolor & -- & -- & -- & 2 & 0.06 & 0.5 & -- & -- & -- \\
\hline Cicuta maculata & -- & -- & -- & -- & -- & -- & 2 & 0.01 & 0.5 \\
\hline Teucrium canadense & -- & -- & -- & -- & -- & -- & 8 & 0.14 & 2.0 \\
\hline Totals & & 87.33 & 200.0 & & 109.92 & 200.0 & & 100.69 & 200.0 \\
\hline Bare ground and litter & & 11.24 & & & 6.60 & & & 10.10 & \\
\hline
\end{tabular}


the exotic species included Poa pratensis, Lactuca serriola, and Rumex crispus, all with very low numbers. In the sedge meadows four exotic species were recorded with Mentha arvensis being the most common. Phalaris arundinacea was the dominant species throughout most of the GRSWA lowlands, particularly the marsh. The abundance of Phalaris arundinacea at GRSWA is an indication of past disturbances, particularly the fluctuation of water levels due to attempts to drain these lowlands. Water table fluctuations resulting from large amounts of ground water being removed for irrigation has exacerbated the problem.

The exotic species Morus alba and Robinia pseudoacacia dominated the upland sand forests at GRSWA. These disturbed, poor-quality forests had become established due to the lack of fire. Associated shrubs on these wooded sites included the exotics Elaeagnus umbellata, Lonicera maackii, L. $x$ bella, Rhamnus cathartica, and Rosa multiflora, which in many areas created impenetrable thickets. When these forested areas were clear-cut in 2001, no slash was left on the ground, and the woody understory was removed. All that was left were stumps that were cut very close to the ground, along with mostly bare sand and some areas covered with a layer of litter. A majority of the species colonizing these areas were exotic and native weedy species.

Endangered Species: Few endangered and threatened species were encountered in GRSWA, probably the result of poor management prior to 1993. Botrychium matricariifolium was the only endangered species found at the GRSWA, occurring at the edge of a mesic sand prairie beneath individuals of Lonicera maackii. Three threatened species were found: Lechea intermedia, Orobanche ludoviciana, and Platanthera flava var. helbiola (Herkert and Ebinger 2002, Illinois Endangered Species Protection Board 2005).

Dry Sand Prairie: The dry sand prairie at GRSWA was similar to the one located at Foley Nature Preserve (FNP; McFall and Karnes

Table 11. Frequency (\%), mean cover (\% of total cover), and importance value (IV) of the ground layer species encountered in late summer of 2002 and again in 2006 and 2007 in a Sparganium eurycarpum vegetation zone in the marsh at the western edge of the Green River State Wildlife Area, Lee County, Illinois. (n=50) (*exotic species)

\begin{tabular}{|c|c|c|c|c|c|c|c|c|c|}
\hline \multirow{3}{*}{ Species } & \multicolumn{3}{|c|}{ Summer 2002} & \multicolumn{3}{|c|}{ Summer 2006} & \multicolumn{3}{|c|}{ Summer 2007} \\
\hline & Freq. & Mean & & Freq. & Mean & & Freq. & Mean & \\
\hline & $\%$ & Cover & IV & $\%$ & Cover & IV & $\%$ & Cover & IV \\
\hline Sparganium eurycarpum & 100 & 45.55 & 91.2 & -- & -- & -- & 14 & 0.56 & 5.4 \\
\hline Persicaria coccinea & 100 & 19.54 & 53.8 & 96 & 33.31 & 42.9 & 100 & 48.73 & 90.1 \\
\hline Urtica gracilis & 84 & 0.47 & 22.3 & 74 & 18.45 & 27.2 & -- & -- & - \\
\hline Schoenoplectus acutus & 40 & 2.25 & 13.5 & -- & -- & -- & -- & -- & -- \\
\hline Rorippa palustris & 44 & 1.35 & 13.3 & 12 & 0.26 & 2.2 & -- & -- & -- \\
\hline *Phalaris arundinacea & 10 & 0.05 & 2.7 & 2 & 0.06 & 0.4 & 8 & 1.12 & 4.0 \\
\hline Amaranthus hybridus & 8 & 0.04 & 2.1 & 2 & 0.01 & 0.3 & -- & -- & -- \\
\hline *Potentilla norvegica & 4 & 0.02 & 1.1 & 6 & 0.42 & 1.3 & -- & -- & -- \\
\hline Persicaria pensylvanica & -- & -- & -- & 80 & 24.35 & 32.9 & 22 & 0.70 & 8.3 \\
\hline *Chenopodium album & -- & -- & -- & 94 & 9.29 & 22.9 & -- & -- & -- \\
\hline Persicaria punctata & -- & -- & -- & 56 & 9.06 & 16.6 & 78 & 12.70 & 41.0 \\
\hline *Mentha arvensis & -- & -- & -- & 44 & 6.78 & 12.7 & 4 & 0.02 & 1.5 \\
\hline Aster praealtus & -- & -- & -- & 32 & 8.05 & 11.7 & 2 & 0.01 & 0.7 \\
\hline Cuscuta gronovii & -- & -- & -- & 38 & 2.96 & 8.6 & -- & -- & -- \\
\hline Ambrosia artemisiifolia & -- & -- & -- & 24 & 4.55 & 7.6 & -- & -- & -- \\
\hline *Cirsium arvense & -- & -- & -- & 20 & 1.80 & 4.8 & -- & -- & -- \\
\hline Persicaria lapathifolia & -- & -- & -- & 12 & 1.56 & 3.3 & 2 & 0.01 & 0.7 \\
\hline *Persicaria vulgaris & -- & -- & -- & 10 & 1.26 & 2.6 & 4 & 0.12 & 1.5 \\
\hline Bolboschoenus fluviatilis & -- & -- & -- & 4 & 0.36 & 1.0 & 60 & 22.95 & 46.8 \\
\hline Lycopus americanus & -- & -- & -- & 2 & 0.30 & 0.5 & -- & -- & -- \\
\hline Solidago gigantea & -- & -- & -- & 2 & 0.30 & 0.5 & -- & -- & -- \\
\hline Totals & & 69.27 & 200.0 & & 123.13 & 200.0 & & 86.92 & 200.0 \\
\hline Bare ground and litter & & 25.74 & & & 6.75 & & & 23.90 & \\
\hline
\end{tabular}


1995, McClain et al. 2003). Located in the extreme western part of Lee County (SW1/4 S7 T20N R8E), this preserve covers the entire ridge and slopes of a small dune, and contains a 2.8-ha dry to dry-mesic sand prairie remnant. Schizachyrium scoparium dominated both areas and many forbs were common to both sites. Common forbs at FNP were Euphorbia corollata, Aster ericoides, Echinacea pallida, Coreopsis palmata, and Ambosia psilostachya, while
Amorpha canescens was the common shrub Species diversity at FNP was higher than at the GRSWA, however, and more conservative prairie species were present as indicated by an FQI of 52.98 and a mean CC of 3.96 (McClain et al. 2003) compared to an FQI of 36.16 and a mean CC of 3.73 at GRSWA. This may be the result of an older, more aggressive management program at the former, athough disturbance prior to public acquisition was probably more

Table 12. Frequency (\%), mean cover (\% of total cover), and importance value (IV) of the ground layer species encountered in late summer of 2002 and again in 2006 and 2007 in a Carex lacustris vegetation zone in the marsh at the western edge of the Green River State Wildlife Area, Lee County, Illinois. $(n=50)$ (*exotic species)

\begin{tabular}{|c|c|c|c|c|c|c|c|c|c|}
\hline \multirow{3}{*}{ Species } & \multicolumn{3}{|c|}{ Summer 2002} & \multicolumn{3}{|c|}{ Summer 2006} & \multicolumn{3}{|c|}{ Summer 2007} \\
\hline & Freq. & Mean & & Freq. & Mean & & Freq. & Mean & \\
\hline & $\%$ & Cover & IV & $\%$ & Cover & IV & $\%$ & Cover & IV \\
\hline Carex lacustris & 100 & 42.80 & 75.4 & 100 & 29.95 & 32.4 & 100 & 38.85 & 51.7 \\
\hline Persicaria coccinea & 100 & 36.45 & 69.1 & 100 & 55.40 & 47.8 & 100 & 51.20 & 61.4 \\
\hline Calamagrostis canadensis & 38 & 18.35 & 30.8 & 46 & 8.10 & 11.5 & 42 & 20.40 & 24.9 \\
\hline Lysimachia thyrsiflora & 18 & 0.82 & 6.7 & 4 & 0.07 & 0.6 & 10 & 0.05 & 2.1 \\
\hline Lycopus uniflorus & 16 & 0.52 & 5.7 & 6 & 0.08 & 0.9 & 4 & 0.31 & 1.1 \\
\hline Persicaria punctata & 16 & 0.23 & 5.4 & 16 & 0.13 & 2.4 & 16 & 0.38 & 3.7 \\
\hline Scutellaria galericulata & 4 & 0.07 & 1.4 & 6 & 0.08 & 0.9 & -- & -- & -- \\
\hline Teucrium canadense & 4 & 0.07 & 1.4 & 32 & 1.43 & 5.5 & 54 & 4.06 & 14.6 \\
\hline Rumex orbiculatus & 2 & 0.30 & 1.0 & -- & -- & -- & 2 & 0.30 & 0.6 \\
\hline Aster praealtus & 2 & 0.06 & 0.8 & 22 & 4.83 & 6.0 & 30 & 7.94 & 12.6 \\
\hline Lycopus americanus & 2 & 0.06 & 0.8 & 14 & 1.09 & 2.7 & 2 & 0.06 & 0.5 \\
\hline Polygonum ramosissimum & 2 & 0.06 & 0.8 & 34 & 1.05 & 5.5 & 44 & 0.57 & 9.8 \\
\hline * Mentha arvensis & 2 & 0.01 & 0.7 & 20 & 2.25 & 4.3 & 8 & 0.43 & 2.0 \\
\hline Ambrosia artemisiifolia & -- & -- & -- & 100 & 38.16 & 37.3 & 4 & 0.02 & 0.9 \\
\hline *Chenopodium album & -- & -- & -- & 84 & 10.83 & 18.6 & -- & -- & -- \\
\hline Cirsium discolor & -- & -- & -- & 26 & 1.25 & 4.5 & 2 & 0.01 & 0.4 \\
\hline Galium obtusum & -- & -- & -- & 10 & 3.56 & 3.6 & -- & -- & -- \\
\hline Solidago gigantea & -- & -- & -- & 10 & 2.21 & 2.7 & 4 & 0.02 & 0.9 \\
\hline Ambrosia trifida & -- & -- & -- & 10 & 1.71 & 2.4 & -- & -- & -- \\
\hline Stachys pilosa & -- & -- & -- & 12 & 1.03 & 2.3 & 10 & 0.10 & 2.2 \\
\hline Oenothera biennis & -- & -- & -- & 10 & 0.44 & 1.7 & -- & -- & -- \\
\hline *Potentilla norvegica & -- & -- & -- & 10 & 0.15 & 1.5 & 4 & 0.07 & 1.0 \\
\hline Physalis subglabrata & -- & -- & -- & 6 & 0.42 & 1.2 & -- & -- & -- \\
\hline Lathyrus palustris & -- & -- & -- & 6 & 0.13 & 1.0 & 2 & 0.06 & 0.5 \\
\hline Verbena hastata & -- & -- & -- & 4 & 0.31 & 0.8 & -- & -- & -- \\
\hline Lactuca canadensis & -- & -- & -- & 4 & 0.12 & 0.7 & 2 & 0.01 & 0.4 \\
\hline Hackelia virginiana & -- & -- & -- & 2 & 0.01 & 0.3 & -- & -- & -- \\
\hline *Nepeta cataria & -- & -- & -- & 2 & 0.01 & 0.3 & -- & -- & -- \\
\hline Solidago canadensis & -- & -- & -- & 2 & 0.06 & 0.3 & -- & -- & -- \\
\hline *Taraxacum officinale & -- & -- & -- & 2 & 0.01 & 0.3 & -- & -- & -- \\
\hline Carex haydenii & -- & -- & -- & -- & -- & -- & 18 & 2.46 & 5.7 \\
\hline Iris shrevei & -- & -- & -- & -- & -- & -- & 2 & 0.06 & 0.5 \\
\hline *Phalaris arundinacea & -- & -- & -- & -- & -- & -- & 2 & 0.06 & 0.5 \\
\hline Asclepias incarnata & -- & -- & -- & -- & -- & -- & 2 & 0.01 & 0.4 \\
\hline Euthamia graminifolia & -- & -- & -- & -- & -- & -- & 2 & 0.01 & 0.4 \\
\hline *Morus alba & -- & -- & -- & -- & -- & -- & 2 & 0.01 & 0.4 \\
\hline Persicaria vulgaris & -- & -- & -- & -- & -- & -- & 2 & 0.01 & 0.4 \\
\hline Cardamine parviflora & -- & -- & -- & -- & -- & -- & 2 & 0.01 & 0.4 \\
\hline Totals & & 99.80 & 200.0 & & 164.87 & 200.0 & & 127.4 & 200.0 \\
\hline & & & & & & & & 7 & \\
\hline Bare ground and litter & & 1.60 & & & 5.14 & & & 12.38 & \\
\hline
\end{tabular}


Table 13. Density (stems/ha) of seedlings, saplings, and trees, basal area (m2/ha); relative values, importance value (IV), and average diameter $(\mathrm{cm})$ of the woody species $(>10.0 \mathrm{~cm} \mathrm{dbh})$ encountered in six wooded areas, Green River State Wildlife Area, Lee County, Illinois. (*exotic species)

\begin{tabular}{|c|c|c|c|c|c|c|c|c|c|}
\hline \multirow[t]{2}{*}{ Species } & \multirow{2}{*}{$\begin{array}{l}\text { Seed- } \\
\text { lings }\end{array}$} & \multicolumn{2}{|c|}{ Saplings } & \multirow{2}{*}{$\begin{array}{r}\text { Trees } \\
\text { \#/ha }\end{array}$} & \multirow{2}{*}{$\begin{array}{l}\text { Basal } \\
\text { Area } \\
\mathrm{m}^{2} / \mathrm{ha}\end{array}$} & \multirow{2}{*}{$\begin{array}{l}\text { Rel. } \\
\text { Den. }\end{array}$} & \multirow{2}{*}{$\begin{array}{l}\text { Rel. } \\
\text { Dom. }\end{array}$} & \multirow[b]{2}{*}{ IV } & \multirow{2}{*}{$\begin{array}{r}\text { Av. } \\
\text { Diam. } \\
\mathrm{cm}\end{array}$} \\
\hline & & Small & Large & & & & & & \\
\hline \multicolumn{10}{|l|}{ Site \# 1} \\
\hline Acer saccharinum & 1500 & 700 & 640 & 765 & 38.085 & 89.5 & 68.9 & 158.4 & 22.8 \\
\hline Populus deltoids & -- & -- & -- & 30 & 10.735 & 3.5 & 19.4 & 22.9 & 65.0 \\
\hline Salix nigra & -- & -- & -- & 35 & 6.010 & 4.1 & 10.9 & 15.0 & 45.5 \\
\hline Acer negundo & -- & -- & 40 & 20 & 0.385 & 2.3 & 0.7 & 3.0 & 15.1 \\
\hline Prunus serotina & -- & -- & -- & 5 & 0.065 & 0.6 & 0.1 & 0.7 & 12.7 \\
\hline Others & 7000 & 3300 & 60 & -- & -- & -- & -- & -- & -- \\
\hline Totals & 8500 & 4000 & 740 & 855 & 55.280 & 100.0 & 100.0 & 200.0 & \\
\hline \multicolumn{10}{|l|}{ Site \# 2} \\
\hline Acer saccharinum & -- & -- & -- & 295 & 20.365 & 67.8 & 73.9 & 141.7 & 27.2 \\
\hline Prunus serotina & 500 & 50 & 40 & 100 & 5.590 & 23.0 & 20.3 & 43.3 & 24.7 \\
\hline Juglans nigra & -- & -- & -- & 20 & 0.820 & 4.6 & 3.0 & 7.6 & 21.0 \\
\hline Fraxinus pennsylvanica & -- & 350 & -- & 20 & 0.775 & 4.6 & 2.8 & 7.4 & 20.6 \\
\hline Others & 6500 & 5600 & 20 & -- & -- & -- & -- & -- & -- \\
\hline Totals & 7000 & 6000 & 60 & 435 & 27.550 & 100.0 & 100.0 & 200.0 & \\
\hline \multicolumn{10}{|l|}{ Site \# 3} \\
\hline Acer saccharinum & 2000 & -- & -- & 225 & 26.345 & 52.3 & 77.4 & 129.7 & 35.5 \\
\hline Prunus serotina & 500 & 50 & 80 & 100 & 4.290 & 23.3 & 12.6 & 35.9 & 21.9 \\
\hline Fraxinus pennsylvanica & -- & 200 & 40 & 25 & 0.530 & 5.8 & 1.6 & 7.4 & 15.2 \\
\hline Populus deltoides & -- & -- & -- & 10 & 1.325 & 2.3 & 3.9 & 6.2 & 41.1 \\
\hline Quercus velutina & -- & -- & 40 & 20 & 0.515 & 4.7 & 1.5 & 6.2 & 17.5 \\
\hline Acer negundo & -- & 100 & -- & 20 & 0.375 & 4.7 & 1.1 & 5.8 & 15.0 \\
\hline *Maclura pomifera & -- & -- & 20 & 10 & 0.350 & 2.3 & 1.0 & 3.3 & 21.1 \\
\hline *Morus alba & -- & 100 & 140 & 10 & 0.170 & 2.3 & 0.5 & 2.8 & 14.3 \\
\hline Celtis occidentalis & -- & 200 & 20 & 10 & 0.120 & 2.3 & 0.4 & 2.7 & 12.4 \\
\hline Others & 13500 & 6200 & -- & -- & -- & -- & -- & -- & - \\
\hline Totals & 16000 & 6850 & 340 & 430 & 34.020 & 100.0 & 100.0 & 200.0 & \\
\hline \multicolumn{10}{|l|}{ Site \# 4} \\
\hline Acer saccharinum & -- & 100 & 20 & 345 & 24.690 & 75.0 & 80.8 & 155.8 & 28.0 \\
\hline Prunus serotina & 1000 & -- & -- & 115 & 5.885 & 25.0 & 19.2 & 44.2 & 24.5 \\
\hline Others & 5000 & 3300 & -- & -- & -- & -- & -- & -- & -- \\
\hline Totals & 6000 & 3400 & 20 & 460 & 30.575 & 100.0 & 100.0 & 200.0 & \\
\hline \multicolumn{10}{|l|}{ Site \# 5} \\
\hline *Morus alba & -- & 50 & 260 & 215 & 4.330 & 38.4 & 13.9 & 52.3 & 15.3 \\
\hline Prunus serotina & -- & 50 & -- & 100 & 9.605 & 17.9 & 30.7 & 48.6 & 30.7 \\
\hline Populus deltoides & -- & -- & -- & 35 & 8.180 & 6.2 & 26.1 & 32.3 & 53.7 \\
\hline Celtis occidentalis & 500 & 50 & 160 & 105 & 1.805 & 18.8 & 5.8 & 24.6 & 14.1 \\
\hline Juglans nigra & 500 & -- & -- & 55 & 2.865 & 9.8 & 9.2 & 19.0 & 29.2 \\
\hline Acer negundo & -- & 100 & 20 & 40 & 1.675 & 7.1 & 5.4 & 12.5 & 20.3 \\
\hline Acer saccharinum & -- & -- & -- & 5 & 2.555 & 0.9 & 8.2 & 9.1 & 80.7 \\
\hline Quercus velutina & 1000 & -- & 20 & 5 & 0.215 & 0.9 & 0.7 & 1.6 & 23.5 \\
\hline Others & 4000 & 5150 & -- & -- & -- & -- & -- & -- & -- \\
\hline Totals & 6000 & 5400 & 460 & 560 & 31.230 & 100.0 & 100.0 & 200.0 & \\
\hline \multicolumn{10}{|l|}{ Site \# 6} \\
\hline Prunus serotina & 1000 & -- & -- & 225 & 15.680 & 60.0 & 76.0 & 136.0 & 29.0 \\
\hline * Robinia pseudoacacia & 10000 & 2200 & -- & 150 & 4.960 & 40.0 & 24.0 & 64.0 & 19.9 \\
\hline Others & 4000 & 1000 & -- & -- & -- & -- & -- & -- & - \\
\hline Totals & 15000 & 3200 & -- & 375 & 20.640 & 100.0 & 100.0 & 200.0 & \\
\hline
\end{tabular}


important. The low numbers of exotic taxa, along with presence of native and conservative prairie taxa, indicate that both sites were recovering from past disturbances.

The dry sand prairie at GRSWA is also similar to a small prairie remnant at the Richardson Wildlife Foundation (RWF). Located about 13 $\mathrm{km}$ east of Amboy, Lee County, Illinois (S13, S14, S3, S24, T20N R11E), the RWF is located near the southwestern edge of what was the Great Inlet Swamp (Killey 1998, Handel et al. 2003). This swamp covered approximately 12,000 ha, and existed because of the Dewey Dam, a natural limestone obstruction $8 \mathrm{~km}$ northeast of the town of Amboy, which prevented channel formation by the Green River (Lyman 1901). In the late 1880s, work began to drain this extensive swamp. Efforts to save the swamp and keep it as a wildlife sanctuary failed, and by 1901 the swamp was gone (McClain 1992, McClain and Ebinger 2000). After drainage most of the Great Inlet Swamp

Table 14. Frequency (\%), mean cover (\% of total cover), and importance value (IV) of the ground layer species (with IV's >2.0) encountered in 2002, 2003, and 2006 in a successional lowland area cleared of trees in the winter of 2001, Green River State Wildlife Area, Lee County, Illinois. ( $\mathrm{n}=100)$ (*exotic species)

\begin{tabular}{|c|c|c|c|c|c|c|c|c|c|}
\hline \multirow[b]{3}{*}{ Species } & \multicolumn{3}{|c|}{ Summer 2006} & \multicolumn{3}{|c|}{ Summer 2003} & \multicolumn{3}{|c|}{ Summer 2002} \\
\hline & Freq. & Mean & & Freq. & Mean & & Freq. & Mean & \\
\hline & $\%$ & Cover & IV & $\%$ & Cover & IV & $\%$ & Cover & IV \\
\hline *Phalaris arundinacea & 96 & 28.49 & 46.0 & 92 & 37.49 & 63.7 & 76 & 28.93 & 52.1 \\
\hline Solidago canadensis & 71 & 15.82 & 27.6 & 48 & 0.89 & 7.6 & -- & -- & -- \\
\hline Persicaria pensylvanica & 71 & 4.43 & 13.4 & 57 & 4.32 & 13.5 & 65 & 20.52 & 38.8 \\
\hline *Lactuca serriola & 61 & 4.48 & 12.4 & 9 & 0.17 & 1.4 & -- & -- & -- \\
\hline *Chenopodium album & 79 & 1.18 & 10.2 & 17 & 0.70 & 3.3 & 1 & 0.15 & 0.4 \\
\hline Carex cristatella & 53 & 2.28 & 8.7 & -- & -- & -- & -- & -- & -- \\
\hline Cirsium discolor & 45 & 2.64 & 8.3 & 1 & 0.03 & 0.1 & -- & -- & -- \\
\hline *Verbascum Thapsus & 53 & 0.61 & 6.7 & 7 & 0.16 & 1.1 & 3 & 0.04 & 0.6 \\
\hline *Cirsium arvense & 28 & 2.62 & 6.4 & -- & -- & -- & -- & -- & -- \\
\hline Eupatorium serotinum & 40 & 1.49 & 6.3 & 31 & 1.36 & 6.0 & 21 & 1.20 & 5.2 \\
\hline Persicaria coccinea & 22 & 2.58 & 5.7 & 38 & 3.48 & 9.9 & 26 & 2.56 & 7.8 \\
\hline Solidago gigantea & 17 & 2.05 & 4.5 & -- & -- & -- & -- & -- & -- \\
\hline Ambrosia artemisiifolia & 21 & 1.54 & 4.2 & 4 & 0.59 & 1.3 & -- & -- & -- \\
\hline Populus deltoides & 16 & 1.95 & 4.2 & 40 & 4.39 & 11.3 & 33 & 2.25 & 8.6 \\
\hline Oenothera biennis & 26 & 0.62 & 3.7 & -- & -- & -- & 1 & 0.15 & 0.4 \\
\hline Acalypha rhomboidea & 28 & 0.39 & 3.6 & 14 & 0.15 & 2.1 & -- & -- & -- \\
\hline *Fallopia convolvulus & 27 & 0.44 & 3.5 & 5 & 0.08 & 0.8 & -- & -- & -- \\
\hline Stachys pilosa & 13 & 1.11 & 2.8 & 5 & 0.22 & 1.0 & -- & -- & -- \\
\hline *Morus tatarica & 13 & 0.56 & 2.1 & 18 & 1.05 & 3.9 & 21 & 0.43 & 4.2 \\
\hline Solanum carolinense & 11 & 0.64 & 2.0 & -- & -- & -- & -- & -- & -- \\
\hline Solanum ptychanthum & 10 & 0.05 & 1.2 & 9 & 0.10 & 1.3 & 9 & 0.58 & 2.4 \\
\hline Bidens vulgata & 5 & 0.08 & 0.7 & 7 & 1.37 & 2.8 & 1 & 0.15 & 0.4 \\
\hline Phytolacca americana & 1 & 0.38 & 0.6 & 3 & 0.07 & 0.5 & 12 & 0.84 & 3.1 \\
\hline Carex sp. & 2 & 0.01 & 0.2 & 45 & 1.98 & 8.7 & -- & -- & -- \\
\hline *Setaria faberi & 2 & 0.01 & 0.2 & 15 & 0.72 & 3.0 & 2 & 0.18 & 0.6 \\
\hline Conyza canadensis & -- & -- & -- & 57 & 4.47 & 13.8 & -- & -- & -- \\
\hline *Potentilla norvegica & -- & -- & -- & 42 & 4.97 & 12.4 & 26 & 0.50 & 5.1 \\
\hline *Persicaria cespitosa & -- & -- & -- & 29 & 1.29 & 5.7 & 30 & 2.58 & 8.6 \\
\hline Amaranthus tuberculatus & -- & -- & -- & 17 & 0.11 & 2.5 & -- & -- & -- \\
\hline *Digitaria sanguinalis & -- & -- & -- & 12 & 0.36 & 2.1 & 11 & 0.33 & 2.3 \\
\hline Cyperus strigosus & -- & -- & -- & 8 & 0.04 & 1.2 & 46 & 0.48 & 8.4 \\
\hline Eleocharis ovata & -- & -- & -- & 7 & 0.04 & 1.0 & 35 & 0.23 & 6.2 \\
\hline Lindernia anagallidea & -- & -- & -- & -- & -- & -- & 50 & 2.49 & 11.9 \\
\hline Rorippa palustris & -- & -- & -- & -- & -- & -- & 23 & 1.19 & 6.5 \\
\hline Amaranthus albus & -- & -- & -- & -- & -- & -- & 14 & 2.29 & 5.5 \\
\hline *Amaranthus hybridus & -- & -- & -- & -- & -- & -- & 9 & 1.80 & 3.9 \\
\hline Rotala ramosior & -- & -- & -- & -- & -- & -- & 13 & 0.55 & 2.9 \\
\hline Others & -- & 4.76 & 16.8 & -- & 2.49 & 18.0 & -- & 2.77 & 14.1 \\
\hline Totals & -- & 80.57 & 200.0 & -- & 73.09 & 200.0 & -- & 73.19 & 200.0 \\
\hline Average bare ground and litter & -- & 16.11 & -- & -- & 36.44 & -- & -- & 30.44 & -- \\
\hline
\end{tabular}


was farmed, but many smaller tracts were left for cattle grazing. As of 1999, 15 ha of sand prairie and sedge meadow remnants existed on the RWF.

This dry sand prairie remnant at RWF was more mesic than the dry sand prairie at GRSWA since the dunes in this part of the Green River Lowlands are smaller and the water table is closer to the surface. On this dry sand prairie Sorgastrum nutans dominated, followed by Euthamia graminifolia Schizachyrium scoparium, Solidago nemoralis, Liatris aspera, and Viola sagittata. Diversity was low, with only 46 species, including the exotic Rumex acetosella, Poa pratensis, and Achillea millefolium, recorded (Handel et al. 2003). The FQI of this dry sand prairie was 29.28 and the mean CC was 4.18 .

Dry-mesic Sand Prairie: Sorghastrum nutans was the dominant native grass in the drymesic sand prairies at both GRSWA and RWF (Handel et al. 2003). Andropogon gerardii, in contrast, was important at GRSWA, but nearly absent at RWF. Dichanthelium villosissimum, a low-growing bunch grass, was fifth in importance at GRSWA but was not encountered at RWF. The dominant forbs on the RWF were Solidago nemoralis, Parthenium integrifolium, and Euthamia graminifolia. Only about half of the species were common to both sites; however, RWF was relatively rich in conservative

Table 15. Frequency (\%), mean cover (\% of total cover), and importance value (IV) of the ground layer species (with IVs > 2.0) encountered in 2002, 2003, and 2006 in a successional upland area cleared of trees in the winter of 2001, Green River State Wildlife Area, Lee County, Illinois. ( $n=100)$ (*exotic species)

\begin{tabular}{|c|c|c|c|c|c|c|c|c|c|}
\hline \multirow[b]{3}{*}{ Species } & \multicolumn{3}{|c|}{ Summer 2006} & \multicolumn{3}{|c|}{ Summer 2003} & \multicolumn{3}{|c|}{ Summer 2002} \\
\hline & Freq. & Mean & & Freq. & Mean & & Ereq. & Mean & \\
\hline & $\%$ & Cover & IV & $\%$ & Cover & IV & $\%$ & Cover & IV \\
\hline Rubus pensilvanicus & 55 & 14.30 & 29.4 & 36 & 2.67 & 8.5 & 25 & 0.82 & 6.0 \\
\hline *Verbascum Thapsus & 62 & 5.89 & 17.4 & 78 & 5.57 & 17.9 & 27 & 2.96 & 11.1 \\
\hline *Chenopodium album & 65 & 3.65 & 14.5 & 32 & 0.41 & 4.6 & 44 & 6.12 & 21.0 \\
\hline *Lonicera maackii & 39 & 5.93 & 14.4 & 88 & 11.02 & 27.3 & 60 & 4.28 & 19.6 \\
\hline Prunus serotina & 29 & 5.22 & 11.9 & 68 & 1.91 & 11.3 & 22 & 0.31 & 4.6 \\
\hline Rubus occidentalis & 30 & 4.78 & 11.4 & 16 & 1.20 & 3.9 & 3 & 0.45 & 1.4 \\
\hline Ambrosia artemisiifolia & 43 & 3.47 & 11.1 & 26 & 1.44 & 5.3 & 4 & 0.60 & 2.1 \\
\hline *Robinia pseudoacacia & 36 & 3.11 & 9.7 & 30 & 2.20 & 7.0 & 23 & 0.87 & 5.8 \\
\hline Conyza canadensis & 45 & 2.10 & 9.3 & 96 & 26.50 & 51.3 & 5 & 0.37 & 1.6 \\
\hline Lactuca canadensis & 44 & 1.04 & 7.6 & -- & -- & -- & 3 & 0.07 & 0.5 \\
\hline Solidago canadensis & 26 & 2.64 & 7.6 & 4 & 0.07 & 0.6 & 2 & 0.06 & 0.4 \\
\hline Cyperus lupulinus & 44 & 0.98 & 7.5 & 68 & 3.09 & 13.0 & 3 & 0.04 & 0.5 \\
\hline *Alliaria petiolata & 41 & 0.87 & 6.9 & -- & -- & -- & 41 & 2.18 & 11.8 \\
\hline Phytolacca americana & 14 & 2.52 & 5.8 & 24 & 1.29 & 4.9 & 83 & 11.16 & 38.8 \\
\hline Prunus virginiana & 15 & 2.46 & 5.8 & 8 & 0.33 & 1.5 & 17 & 0.53 & 4.0 \\
\hline Smilacina stellata & 20 & 0.50 & 3.4 & 2 & 0.06 & 0.4 & 2 & 0.02 & 0.4 \\
\hline Dichanthelium villosissimum & 14 & 0.54 & 2.7 & 4 & 0.12 & 0.7 & 4 & 0.10 & 0.9 \\
\hline *Phalaris arundinacea & 10 & 0.64 & 2.4 & 8 & 0.67 & 2.0 & 2 & 0.18 & 0.7 \\
\hline Solanum carolinense & 9 & 0.73 & 2.3 & 8 & 0.19 & 1.3 & -- & -- & -- \\
\hline Oxalis stricta & 14 & 0.07 & 2.0 & 10 & 0.05 & 1.3 & 1 & 0.01 & 0.2 \\
\hline Parthenocissus quinquefolia & 8 & 0.43 & 1.8 & 8 & 0.67 & 2.0 & 6 & 0.30 & 1.7 \\
\hline Carex molesta & 5 & 0.39 & 1.3 & 14 & 1.09 & 3.3 & -- & -- & -- \\
\hline Quercus velutina & 3 & 0.45 & 1.1 & 14 & 0.22 & 2.0 & 1 & 0.03 & 0.3 \\
\hline Dichanthelium oligosanthes & 5 & 0.08 & 0.8 & 28 & 2.29 & 6.9 & 7 & 0.28 & 1.7 \\
\hline Muhlenbergia schreberi & 3 & 0.02 & 0.4 & 12 & 1.00 & 3.0 & 7 & 0.51 & 2.2 \\
\hline Solanum ptychanthum & 2 & 0.01 & 0.3 & 14 & 0.17 & 2.0 & 67 & 8.88 & 31.0 \\
\hline Chenopodium standleyanum & 1 & 0.03 & 0.2 & -- & -- & -- & 11 & 1.23 & 4.5 \\
\hline Polygala polygama & -- & -- & -- & 20 & 0.54 & 3.3 & 10 & 0.05 & 1.8 \\
\hline Dichanthelium acuminatum & -- & -- & -- & 14 & 0.80 & 2.9 & 6 & 0.06 & 1.1 \\
\hline Cyperus schweinitzii & -- & -- & -- & 8 & 0.38 & 1.6 & 64 & 1.36 & 13.7 \\
\hline Others & -- & 2.34 & 11.0 & -- & 1.35 & 10.2 & -- & 1.11 & 10.6 \\
\hline Totals & -- & 65.19 & 200.0 & -- & 67.30 & 200.0 & -- & 44.94 & 200.0 \\
\hline Average bare ground and litter & -- & 26.68 & -- & -- & 31.68 & -- & -- & 51.40 & -- \\
\hline
\end{tabular}


species that were not found at GRSWA. The FQI was 41.88 and the mean CC was 4.44 at RWF (compared to FQI of 37.77, mean CC of 3.74 at GRSWA).

Mesic Sand Prairie: The mesic to wet-mesic sand prairies at RWF and GRSWA differed in species composition (Handel et al. 2003). On both sites Sorghastrum nutans and Andropogon gerardii were the dominant tall grasses. Also, at both sites forb diversity was high, but few of the species encountered at the GRSWA were found at RWF, and except for the dominant tall grasses there was almost no similarity between the two sites. The mesic sand prairie at RWF had a higher FQI and mean CC than at GRSWA. Overall, there were fewer native prairie species at GRSWA and most were not conservative species. Past destructive management practices (including food plot plantings, lack of fire, and equestrian use) at GRSWA prior to 1993 were probably responsible for these differences.

Wet Sand Prairie: The only wet sand prairie examined in the Green River Lowlands was associated with a sedge meadow/mesic prairie area at GRSWA. This plant community is similar in species composition to wet "black soil" prairies with Spartina pectinatus, Calamagrostis canadensis, Thelypteris palustris and various Carex species common (White and Madany 1978). The wet sand prairie at GRSWA, with 102 taxa, had the highest species diversity of all communities encountered. Many were rare species with very specific habitat requirements, some of which were common throughout the wet prairie.

Sedge Meadow: Sedge meadows are relatively common in the preserves of the Green River Lowlands. Two were studied at GRSWA, whereas three at RWF had earlier been examined (Handel et al. 2003). All were similar in having extensive hummocks of Carex haydenii, the dominant species. The species commonly encountered at RWF included Onoclea sensibilis, Thelypteris palustris, Calamagrostis canadensis, Helianthus grosseserratus, Boehmeria cylindrica, Solidago gigantea, and Galium obtusum; many of the same species encountered at the GRSWA sedge meadows. The sedge meadows at RWF averaged between 39 and 54 species, compared to 25 to 29 species at GRSWA. The reason for the lower species diversity at the GRSWA is not known, but is undoubtedly related to the nature of past disturbances, and more active management, especially water table manipulation, at RWF.

Marsh: The only marsh examined in the Green River Lowlands, located at the western edge of the GRSWA, was surveyed in 2002, subjected to an uncontrolled burn in 2005 , and surveyed again in late summer of 2006 and 2007. During 2002 species diversity was very low, composed mainly of species found in many marsh communities throughout most of Illinois (White and Madany 1978). The first year after the 2005 fire, many native weedy species became important, whereas the original dominant species were either absent or present in low numbers. By 2007 many of these native weedy species were greatly reduced in numbers or were absent altogether, whereas many of the species dominant in 2002 were recovering. One exception was Sparganium eurycarpum, which had not recovered by 2007. It appears that this species does not do well after hot fires, many of the rhizomes likely did not survive. Many of the less abundant species that were present in 2002 were not observed in the later surveys as they were never important stand components.

Sand Forest: Based on General Land Office (GLO) survey notes and plats, the presettlement sand deposits of the Green River Lowlands were dominated by sand prairies and marshes. The dominant tree on sand dunes was Quercus velutina, mostly occurring as scattered individuals on dune ridges and protected sites. These savannas consisted of open-growth trees and ground cover dominated by sand prairie grasses and forbs (Curtis 1959, Bray 1960, Nuzzo 1986, White and Madany 1978). In dry sand savannas the soil lacked a dark A horizon and the ground cover was composed of many prairie species with the dominant bunchgrasses, which were typically less than $1 \mathrm{~m}$ tall. These dry sand savannas and forests were associated with dune and swale topography, which probably limited the severity of fires. Common lowland species of the Green River Lowlands were probably Acer saccharinum, Celtis occidentalis, Fraxinus pennsylvanica, Populus deltoides, Prunus serotina, and Salix nigra. Frequent prairie fires prevented these fast growing tree species from covering large areas 
of the wetland and lower dune slopes (McClain and Elzinga 1994). These fast-growing, fire-sensitive, shade-intolerant taxa were all common forest components at GRSWA during this study.

The forests present at GRSWA during this study were of recent origin. Post-settlement fire supression had increased the acreage of sand forest at the expense of sand savannas (White and Madany 1978, Anderson and Brown 1986, Anderson 1991, Abrams 1992). These forests, with 80 to $100 \%$ canopy cover, had eliminated the common prairie and marsh plants associated with the dune and swale topography typical of Illinois sand deposits.

Management: The management of prairie and marsh communities at GRSWA since 1993, which has included the use of fire on a regular basis and the active removal of brush and trees, has been important in improving the quality of these communities. The high importance values of some exotic species, particularly Phalaris arundinacea, indicated that some areas were not recovering rapidly from past disturbances. The presence of the native and conservative prairie taxa, however, indicated that the management practices had, in part, been successful. The use of fire is imperative if the upland sand prairie communities are going to increase in quality and species diversity (Bowles et al. 2003).

\section{ACKNOWLEDGMENTS}

The authors thank the Illinois Department of Natural Resources for funding parts of this project through the Illinois Wildlife Preservation Fund as well as other funding sources, the Illinois Nature Preserves Commission for allowing access to the nature preserves, Dr. Gordon Tucker, Eastern Illinois University, for his help in identification of the Cyperaceae, and Ms. Katherine J. Hunter, Illinois Natural History Survey, for digitizing the data on woody encroachment. P. Sorensen and an anonymous reviewer provided constructive comments on the manuscript. 


\section{LITERATURE CITED}

Abrams, M.D. 1992. Fire and the development of oak forests. BioScience 42:346353.

Anderson, R.C. 1991. Presettlement forest of Illinois. Pages 9-19 in G.V. Burger, J.E. Ebinger, and G.S. Wilhelm, eds. Proceedings of the Oak Woods Management Workshop. Eastern Illinois University, Charleston.

Anderson, R.C., and L.E. Brown. 1986. Stability and instability in plant communities following fire. American Journal of Botany 73:364-368.

Bailey, A.W., and C.E. Poulton. 1968. Plant communities and environmental relationships in a portion of the Tillamook burn, northwestern Oregon. Ecology 49:1-13.

Bowles, M.L., M.D. Jones, and J.L. McBride. 2003. Twenty-year changes in burned and unburned sand prairie remnants in northwestern Illinois and implications for management. American Midland Naturalist 149:35-45.

Bray, J.R. 1960. The composition of savanna vegetation in Wisconsin. Ecology 41:721-732.

Curtis, J.T. 1959. The vegetation of Wisconsin. The University of Wisconsin Press, Madison. 657 pp.

Daubenmire, R. 1959. A canopy coverage method of vegetation analysis. Northwest Science 33:43-64.
Ebinger, J.E., L.R. Phillippe, W.C. Handel, C.J. Cunningham, W.E. McClain, R.N. Nyboer, and T. Bittner. 2008. Plant communities of the Green River Lowlands in northwestern Illinois. Illinois Natural History Survey, Center for Biodiversity Technical Report 2008 (21). Unpublished report prepared for the Illinois Department of Natural Resources, Division of Natural Heritage, Springfield.

Gleason, H.A. 1910. The vegetation of the inland sand deposits of Illinois. Bulletin of the Illinois State Laboratory of Natural History 9:21-174.

Gleason, H.A., and A. Cronquist. 1991. Manual of the vascular plants of northeastern United States and adjacent Canada. Second Edition. The New York Botanical Garden, The Bronx. 1xxv+910 pp.

Handel, W.C., L.R. Phillippe, and J.E. Ebinger. 2003. Floristic assessment of sand prairies and sedge meadows, Lee County, Illinois. The Prairie Naturalist 35:33-46.

Herkert, J.R., and J.E. Ebinger. 2002. editors. Endangered and threatened species of Illinois: status and distribution. Volume 1: Plants. Endangered Species Protection Board, Springfield. 161 pp.

Illinois Endangered Species Protection Board. 2005. Checklist of endangered and threatened animals and plants of Illinois. Illinois Endangered Species Protection Board, Illinois Department of Natural Resources, Springfield. 16 pp. 
Killey, M.M. 1998. Glacial and surfical geology. Pages 15-19 in Lower Rock River Area Assessment. Volume 1. Geology (no editor), Critical Trends Assessment Program, Illinois Department of Natural Resources and the State Geological Survey Division, Champaign.

King, J.E. 1981. Late Quaternary vegetational history of Illinois. Ecological Monographs 51:43-62.

Lavergne, S., and J. Molofsky. 2006. Control strategies for the invasive reed canarygrass (Phalaris arundinacea $\mathrm{L}$.) in North American wetlands: the need for an integrated management plan. Natural Areas Journal 26:208-214.

Lyman, G.A. 1901. Inlet Swamp and Inlet Drainage District. A history of the district from its organization to the completion of the work. The Amboy Journal. Amboy, Illinois.

McClain, W.E. 1992. Wetlands that were. Illinois Audubon 240:5-7.

McClain, W.E., and J.E. Ebinger. 2000. Dreams not realized: early attempts at land preservation in Illinois. Illinois Steward 9(4):4-8.

McClain, W.E., and S.L. Elzinga. 1994. The occurrence of prairie and forest fires in Illinois and other midwestern states, 1679 to 1854 . Erigenia 13:79-90.

McClain, W.E., L.R. Phillippe, and J.E. Ebinger. 2003. Floristic assessment of Foley Sand Prairie Nature Preserve, Lee County, Illinois. Transactions of the Illinois State Academy of Science 96:255-263.
McFall, D., and J. Karnes. 1995. editors. A directory of Illinois Nature Preserves. Volume 2. Northwestern, central, and southern Illinois. Illinois Department of Natural Resources, Springfield. 327 pp.

McIntosh, R.P. 1957. The York Woods. A case history of forest succession in southern Wisconsin. Ecology 38:29-37.

Midwestern Regional Climate Center. 2008. http://mcc.sws.uiuc.edu

Mohlenbrock, R.H. 2002. Vascular flora of Illinois. Southern Illinois University Press, Carbondale. 490 pp.

Mueller-Dombois, D., and H. Ellenberg. 1974. Aims and methods of vegetation ecology. John Wiley and Sons, New York.

Nuzzo, V.A. 1986. Extent and status of Midwest oak savanna: presettlement and 1985. Natural Areas Journal 6:6-36.

Phillippe, L.R., J.E. Ebinger, R. Nyboer, D.T. Busemeyer, and K.J. Hunter. 2003. Vegetation analysis of forest communities before and after cutting, and the evaluation of potential natural areas at the Green River State Conservation Area, Lee County, Illinois. Illinois Natural History Survey, Center for Biodiversity Technical Report 2003 (30). Unpublished report prepared for the Illinois Department of Natural Resources, Division of Natural Heritage, Springfield.

Phillippe, L.R., W.C. Handel, K.J. Hunter, and J.E. Ebinger. 2000. A site inventory of the Green River State Conservation Area, Lee County, Illinois. Illinois Natural History Survey, Center for Biodiversity Technical Report 2000 (29). Unpublished report prepared for the Illinois Department of Natural Resources, Division of Natural Heritage, Springfield. 
Schwegman, J.E. 1973. Comprehensive plan for the Illinois Nature Preserves System. Part 2. The natural divisions of Illinois. Illinois Nature Preserves Commission, Rockford. map+32 pp.

Taft, J.B., G.S. Wilhelm, D.M. Ladd, and L.A. Masters. 1997. Floristic quality assessment for vegetation in Illinois, a method for assessing vegetation integrity. Erigenia 15:1-95.

White, J. 1978. Illinois natural areas inventory. Technical report. Volume I. Survey methods and results. Illinois Natural Areas Inventory, Urbana. xix+426 pp.

White, J., and M.H. Madany. 1978. Classification of natural communities in Illinois. Pages 310-405 in J. White, ed. Illinois natural areas inventory. Technical report. Illinois Natural Areas Inventory, Urbana.

Willman, H.B., and J.C. Frye. 1970. Pleistocene stratigraphy of Illinois. Illinois State Geological Survey Bulletin 94:1-204.

Zwicker, S.E. 1985. Soil survey of Lee County, Illinois. United States Department of Agriculture, Soil Conservation Service in cooperation with the Illinois Agricultural Experiment Station, Champaign. ix $+236 \mathrm{pp}$. 


\begin{abstract}
APPENDIX I
Vascular plant species encountered at Green River State Wildlife Area, Lee County, Illinois, are listed alphabetically by family under major plant groups. Collecting numbers preceded by an $\mathrm{E}$ (John E. Ebinger) are deposited in the Stover-Ebinger Herbarium, Eastern Illinois University, Charleston, Illinois (EIU). Collecting numbers preceded by a P (Loy R. Phillippe) are deposited in the Illinois Natural History Survey Herbarium, Champaign. (ILLS). (*exotic species)
\end{abstract}

\title{
FERNS AND FERN-ALLIES
}

\section{Aspleniaceae}

Asplenium platyneuron (L.) Oakes: P32588

\section{Dryopteridaceae}

Athyrium filix-femina (L.) Martens ssp. angustum (Willd.) R.T. Clausen: P32587

Dryopteris carthusiana (Villars) H.P. Fuchs: P32576

Dryopteris cristata (L.) Gray: P31662

\section{Equisetaceae}

Equisetum arvense L.: $\mathrm{P} 31501$

Equisetum x ferrissii Clute: P31638

Equisetum hyemale L.: P32602

Equisetum laevigatum A. Br.: P31644

\section{Onocleaceae}

Onoclea sensibilis L.: P32370

\section{Ophioglossaceae}

Botrychium dissectum Spreng.: P32530

Botrychium matricariifolium (Doll.) A. Br.: P31628

Botrychium virginianum (L.) Sw.: P31608

\section{Osmundaceae}

Osmunda claytoniana L.: P31483

Osmunda regalis L.: P31577

\section{Thelypteridaceae}

Thelypteris palustris Schott: P32451

\section{GYMNOSPERMS}

\section{Cupressaceae}

Juniperus virginiana L.: P31530

\section{Pinaceae}

* Larix decidua Mill.: P31551

*Pinus banksiana Lamb.: P31529

* Pinus echinata Mill.: P32494

*Pinus strobus L.: P32606

*Pinus sylvestris L.: P32619

*Pseudotsuga taxifolia Britt.: P32675

\section{Taxodiaceae}

*Taxodium distichum (L.) Rich.: P32622 


\title{
MONOCOTS
}

\author{
Alismataceae \\ Alisma subcordatum Raf.: P32411 \\ Alisma triviale Pursh: P32625 \\ Sagittaria latifolia Willd.: P32365
}

\section{Amaryllidaceae}

Hypoxis hirsuta (L.) Coville: P31507

\section{Commelinaceae}

*Commelina communis L.: P32678

Tradescantia ohiensis Raf.: P31474

\section{Cyperaceae}

Bolboschoenus fluviatilis (Torr.) Sojak: P31593

Bulbostylis capillaris (L.) C.B. Clarke: P36135

Carex bicknellii Britt.: P31682

Carex brevior (Dewey) Mack.: P31564

Carex buxbaumii Wahl.: P31613

Carex conoidea Schk.: P31504

Carex cristatella Britt.: P31653

Carex davisii Schwein. \& Torr.: P31579

Carex festucacea Schk.: P31589

Carex haydenii Dewey: P31587

Carex lacustris Willd.: P34952

Carex molesta Mack.: P35666

Carex muhlenbergii Schk.: P31562

Carex normalis Mack.: P31713

Carex pellita Willd.: P31633

Carex pensylvanica Lam.: P32641

Carex scoparia Schk.: P36143

Carex stipata Muhl.: P31592

Carex suberecta (Olney) Britt.: P31697

Carex swanii (Fern.) Mack.: P31611

Carex tonsa (Fern.) Bickn.: P31513

Carex tribuloides Vahl: P34684

Carex vesicaria $\mathrm{L} .: \mathrm{P} 31508$

Carex vulpinoidea Michx.: P31687

Cyperus esculentus L.: P32489

Cyperus lupulinus (Spreng.) Marcks var. macilentus (Fern.) Marcks: P32486

Cyperus schweinitzii Torr.: P32608

Cyperus squarrosus L.: P34699

Cyperus strigosus L.: P32412

Eleocharis acicularis (L.) Roem. \& Schultes: P32417

Eleocharis compressa Sull.: P31614

Eleocharis ovata (Roth) Roem. \& Schultes var. detonsa (Gray) Mohlenbr.: P32596

Eleocharis ovata (Roth) Roem. \& Schultes var. obtusa (Willd.) Kukenth: P32415

Eleocharis verrucosa (Svenson) Harms: P31673

Eleocharis wolfii Gray: P31615

Fimbristylis autumnalis (L.) Roem. \& Schultes: P32687

Schoenoplectus acutus (Muhl.) A. Love \& D. Love: P32501

Schoenoplectus heterochaetus (Chase) Sojak: P31683

Scirpus atrovirens Willd.: P32623 
Scirpus cyperinus (L.) Kunth: P32373

Scirpus pendulus Muhl.: P31704

Scleria triglomerata Michx.: P31671

\section{Iridaceae}

*Iris flavescens DC.: P35672

Iris shrevei Small: P31581

Sisyrinchium campestre Bickn.: P31511

\section{Juncaceae}

Juncus acuminatus Michx.: P32413

Juncus dudleyi Wieg.: E28953

Juncus effusus L.: P32473

Juncus greenei Oakes \& Tuckerm.: P31678

Juncus interior Wieg.: P31695

Juncus marginatus Rostk.: P32477

Juncus tenuis Willd.: P31696

Juncus torreyi Coville: P32476

\section{Lemnaceae}

Lemna minor L.: P32626

Lemna trisulca L.: P31657

\section{Liliaceae}

Allium canadense L.: P31685

*Asparagus officinalis L.: P31618

*Hemerocallis fulva (L.) L.: P34599

Lilium michiganense Farw.: P35863

Maianthemum canadense Desf. var. canadense: P31607

Polygonatum commutatum (Schult.) A. Dietr.: P31605

Smilacina stellata (L.) Desf.: P31500

\section{Orchidaceae}

Corallorhiza odontorhiza (Willd.) Nutt.: P32631

Goodyera pubescens (Willd.) R. Br.: P32367

Liparis liliifolia (L.) Rich.: P32418

Liparis loeselii (L.) Rich.: P32577

Platanthera flava (L.) Lindl. var. herbiola (R. Br.) Luer: P31654

Spiranthes cernua (L.) Rich.: P32431

Spiranthes ovalis Lindl.: P34968

\section{Poaceae}

Agrostis gigantea Roth: P31560

Agrostis hyemalis (Walt.) BSP.: R.Evers 108119

Alopecurus carolinianus Walt.: P35654

Andropogon gerardii Vitman: P32354

Aristida basiramea Engelm.: P32521

Aristida intermedia Scribn. \& Ball: P32497

Aristida oligantha Michx.: P32573

Aristida tuberculosa Nutt.: P32560

*Avena sativa L.: P32663

Bouteloua curtipendula (Michx.) Torr.: E28888

Bouteloua hirsuta Lag.: P32569

*Bromus commutatus Schrad.: P31718 
*Bromus inermis Leyss.: P31572

*Bromus tectorum L.: P31540

Calamagrostis canadensis (Michx.) P. Beauv.: P31659

Cenchrus longispinus (Hack.) Fern.: E28917

Cinna arundinacea L.: P32531

*Dactylis glomerata L.: P31604

Dichanthelium acuminatum (Sw.) Gould \& Clark var. fasciculatum (Torr.) Freckm.: P31702

Dichanthelium depauperatum (Muhl.) Gould: observed

Dichanthelium oligosanthes (Schult.) Gould var. scribnerianum (Nash) Gould: P31475

Dichanthelium perlongum (Nash) Freckm.: P31557

Dichanthelium villosissimum (Nash) Freckm.: P31569

*Digitaria ischaemum (Schreb.) Schreb.: P32381

* Digitaria sanguinalis (L.) Scop.: E28891

*Echinochloa crus-galli (L.) P. Beauv.: P32414

Echinochloa muricata (Michx.) Fern. var. muricata: P32515

Echinochloa walteri (Pursh) Heller: P34977

*Eleusine indica (L.) Gaertn.: P32648

Elymus canadensis L.: P32572

Elymus villosus Muhl.: P32667

Elymus virginicus L.: P32463

*Elytrigia repens (L.) Desv.: E28909

*Eragrostis cilianensis (All.) Vign.: P34696

Eragrostis frankii C.A. Meyer var. frankii: P32532

Eragrostis hypnoides (Lam.) BSP.: P36136

Eragrostis pectinacea (Michx.) Nees: P34697

Eragrostis spectabilis (Pursh) Steud.: P32427

* Festuca arundinacea Schreb.: P35661

* Festuca pratensis Huds.: E28907

Festuca subverticillata (Pers.) E.B. Alexeev.: P35657

Glyceria septentrionalis Hitchc.: P31652

Glyceria striata (Lam.) Hitchc.: P31656

Heterostipa spartea (Trin.) Barkworth: P31599

Hordeum jubatum L.: P32484

Hordeum pusillum Nutt.: P31583

Koeleria macrantha (Ledeb.) Spreng.: P31602

Leersia oryzoides (L.) Swartz: P32448

Leersia virginica Willd.: P32581

Leptoloma cognatum (Schult.) Chase: E28956

*Lolium perenne L.: P34695

*Miscanthus sacchariflorus (Maxim.) Hack.: P37113

Muhlenbergia frondosa (Poir.) Fern.: P32524

Muhlenbergia mexicana (L.) Trin.: P32375

Muhlenbergia schreberi J.F. Gmel.: P32384

Panicum capillare L.: P32534

Panicum dichotomiflorum Michx.: P32533

Panicum virgatum L.: E28947

Paspalum bushii Nash: E28957

*Phalaris arundinacea L.: P31568

*Phleum pratense L.: E28906

*Phragmites australis (Cav.) Trin.: P32506

*Poa annua L.: P35644

*Poa compressa L.: P31597

*Poa pratensis L.: P31494

Schizachyrium scoparium (Michx.) Nash: P34677 
*Secale cereale L.: P35651

*Setaria faberi R.A.W. Herrm.: P32363

Setaria glauca (L.) P. Beauv.: P32438

* Setaria viridis (L.) P. Beauv.: E28916

Sorghastum nutans (L.) Nash: P32350

Spartina pectinata Link: P32374

Sporobolus cryptandrus (Torr.) Gray: P32426

Sporobolus heterolepis (Gray) Gray: P32496

Sporobolus vaginiflorus (Torr.) A. Wood: P32491

Tridens flavus (L.) Hitchc.: P32586

Triplasis purpurea (Walt.) Chapm.: P32604

*Triticum aestivum L.: P35659

Vulpia octoflora (Walt.) Rydb. var. glauca (Nutt.) Fern.: P31567

Vulpia octoflora (Walt.) Rydb. var. tenella (Willd.) Fern.: P35658

\section{Smilacaceae}

Smilax lasioneuron Hook.: P32518

Smilax tamnoides L.: P32582

\section{Sparganiaceae}

Sparganium eurycarpum Engelm.: P32504

\section{Typhaceae}

Typha angustifolia L.: P34971

Typha latifolia L.: P32595

\section{DICOTS}

\section{Aceraceae}

Acer negundo L.: P31545

Acer saccharinum L.: P31368

\section{Amaranthaceae}

Amaranthus albus L.: P32593

*Amaranthus hybridus L.: P32652

*Amaranthus powellii S. Wats.: P32566

*Amaranthus retroflexus L.: P32660

Amaranthus tuberculatus (Moq.) J. Sauer: P32565

Froelichia floridana (Nutt.) Moq.: E28940

Froelichia gracilis (Hook.) Moq.: P32487

\section{Anacardiaceae}

Rhus aromatica Ait. var. arenaria (Greene) Fern.: P31518

Rhus glabra L.: P31710

Toxicodendron radicans (L.) Kuntze: P31723

\section{Apiaceae}

Angelica atropurpurea L.: P34607

Cicuta maculata L.: P31655

*Conium maculatum L.: P35650

Cryptotaenia canadensis (L.) DC.: P31660

*Daucus carota L.: E28901

Eryngium yuccifolium Michx.: P32544

Osmorhiza claytonii (Michx.) C.B. Clarke: P31612 
Osmorhiza longistylis (Torr.) DC.: P31482

Oxypolis rigidior (L.) Raf.: P32467

*Pastinaca sativa L.: P31570

Polytaenia nuttallii DC.: P31601

Sanicula canadensis L. var. canadensis: P31665

Sanicula odorata (Raf.) Pryer \& Phillippe: P32645

Sium suave Walt.: P32509

Zizia aurea (L.) Koch: P31512

\section{Apocynaceae}

Apocynum cannabinum L.: E28918

Apocynum sibiricum Jacq.: P31686

\section{Ascelpiadaceae}

Asclepias amplexicaulis Small: P31582

Asclepias hirtella (Pennell) Woodson: P31670

Asclepias incarnata L.: E28919

Asclepias sullivantii Engelm.: P31690

Asclepias syriaca L.: P31667

Asclepias verticillata L.: E28944

Asclepias viridiflora Raf.: P31647

\section{Asteraceae}

*Achillea millefolium L.: P31563

Ageratina altissima (L.) R.M. King \& H. Robins.: E28897

Ambrosia artemisiifolia L.: P32353

Ambrosia psilostachya DC.: E28959

Ambrosia trifida L.: P32485

Antennaria neglecta Greene: P31491

Antennaria plantaginifolia (L.) Hook.: P32643

*Arctium minus Schk.: P36134

Arnoglossum plantagineum Raf.: P34676

Artemisia campestris L.: P32391

Aster ericoides L.: P32551

Aster lanceolatus Willd.: P32540

Aster novae-angliae L.: P32466

Aster oblongifolius Nutt.: P32689

Aster ontarionis Wieg.: P32590

Aster oolentangiensis Riddell: P32638

Aster pilosus Willd.: P32555

Aster praealtus Poir.: P34953

Aster puniceus L.: P32460

Aster sericeus Vent.: P32664

Bidens bipinnata L.: P32629

Bidens cernua L.: P32644

Bidens comosa (Gray) Wieg.: P32539

Bidens coronata (L.) Britt.: P32455

Bidens vulgata Greene: P32526

Boltonia asteroides (L.) L'Hér var. recognita (Fern. \& Grisc.) Cronq.: P32420

Brickellia eupatorioides (L.) Shinners: E28949

Chrysopsis camporum Greene: P31565

*Cichorium intybus L.: P34692

*Cirsium arvense (L.) Scop.: E28914

Cirsium discolor (Muhl.) Spreng.: P32390 
*Cirsium vulgare (Savi) Tenore: P32592

Conoclinium coelestinum (L.) DC.: observed

Conyza canadensis (L.) Cronq.: P32352

Coreopsis lanceolata L.: P31558

Coreopsis palmata Nutt.: P32495

Echinacea pallida (Nutt.) Nutt.: P31706

Erechtites hieracifolia (L.) Raf.: P32358

Erigeron annuus (L.) Pers.: P31715

Erigeron philadelphicus L.: P31584

Erigeron strigosus Muhl.: P31561

Eupatoriadelphus maculatus (L.) R.M. King \& H. Robins.: P32456

Eupatoriadelphus purpureus (L.) R.M. King \& H. Robins.: P32671

Eupatorium altissimum L.: P32440

Eupatorium perfoliatum L.: P32369

Eupatorium serotinum Michx.: P32446

Euthamia graminifolia (L.) Nutt.: P34949

Euthamia gymnospermoides Greene: P32349

Helenium autumnale L.: P32464

*Helianthus annuus L.: P34685

Helianthus grosseserratus Martens: E28926

Helianthus occidentalis Riddell: E28943

Helianthus pauciflorus Nutt.: P32428

Helianthus tuberosus L.: P32408

Heliopsis helianthoides (L.) Sweet: P32442

Hieracium longipilum Torr.: E28942

Ionactis linariifolius (L.) Greene: P32570

Krigia virginica (L.) Willd.: P31471

Lactuca canadensis L.: P32366

Lactuca floridana (L.) Gaertn.: P34689

*Lactuca serriola L.: P32653

*Leucanthemum vulgare Lam.: P31711

Liatris aspera Michx.: P32421

Liatris pycnostachya Michx.: E28931

* Matricaria discoidea DC.: P31539

Oligoneuron rigidum (L.) Small: P32424

Parthenium integrifolium L.: P31703

Prenanthes racemosa Michx.: P32610

Pseudognaphalium obtusifolium (L.) Hilliard \& Burtt.: P32382

Ratibida pinnata (Vent.) Barnh.: P32441

Rudbeckia hirta L.: P31643

Rudbeckia subtomentosa Pursh: P32377

Senecio plattensis Nutt.: P31492

Silphium integrifolium Michx.: E28928

Silphium laciniatum L.: P32616

Silphium terebinthinaceum Jacq.: P32682

Solidago canadensis L.: P32549

Solidago gigantea Ait.: P32360

Solidago missouriensis Nutt. var. fasciculata Holz.: E28950

Solidago nemoralis Ait.: P32557

Solidago speciosa Nutt.: P32522

* Sonchus arvensis L. var. glabrescens Grab. \& Wimm.: P32585

*Sonchus asper (L.) Hill: P34608

*Taraxacum officinale Weber: P31479

*Tragopogon dubius Scop.: P31485 
*Tragopogon pratensis L.: P35664

Vernonia fasciculata Michx.: P32434

Xanthium strumarium L. var. canadense (Mill.) Torr. \& Gray: P32568

\title{
Balsamiaceae
}

Impatiens pallida Nutt.: observed

\section{Bignoniaceae}

Campsis radicans (L.) Seem.: E28900

*Catalpa speciosa Warder: P31708

\section{Boraginaceae}

Hackelia virginiana (L.) I.M. Johnston: P32385

Lithospermum croceum Fern.: P31473

Lithospermum incisum Lehm.: P32630

\section{Brassicaceae}

*Alliaria petiolata (Bieb.) Cavara \& Grande: P31480

*Arabidopsis thaliana (L.) Heynh.: P35643

Arabis glabra (L.) Bernh.: P31719

*Barbarea vulgaris R. Br.: P31484

* Berteroa incana (L.) DC.: P31535

*Capsella bursa-pastoris (L.) Medic.: P31369

Cardamine bulbosa (Muhl.) BSP.: P31588

Cardamine pensylvanica Willd.: P31610

Draba reptans (Lam.) Fern.: P31516

*Erysimum cheiranthoides L.: P31527

*Erysimum inconspicuum (S. Wats.) MacM.: P31642

*Erysimum repandum L.: P35648

*Hesperis matrionalis L.: P34610

*Lepidium campestre (L.) R. Br.: P31525

*Lepidium densiflorum Schrad.: P31677

Lepidium virginicum L.: P31476

Nasturtium officinale R. Br.: P31609

Rorippa palustris (L.) Besser var. fernaldiana (Butters \& Abbe) Stuckey: P32600

Rorippa sessiliflora (Nutt.) A. Hitchc.: P32564

*Sisymbrium altissimum L.: P31536

*Sisymbrium loeselii L.: E28905

*Thlaspi arvense L.: P31499

\section{Caesalpiniaceae}

Chamaecrista fasciculata (Michx.) Greene: E28936

\section{Campanulaceae}

Campanula aparinoides Pursh: P32457

Campanulastrum americanum (L.) Small: E28896

Lobelia cardinalis L.: P36133

Lobelia siphilitica L.: P32425

Lobelia spicata Lam.: P31575

Triodanis perfoliata (L.) Neiuwl.: P31622

\section{Cannabinaceae}

\author{
*Cannabis sativa L.: P31646
}




\section{Capparaceae}

Polanisia dodecandra (L.) DC.: P32655

\section{Caprifoliaceae}

*Lonicera x bella Zabel: P 31519, P 32520

*Lonicera maackii (Rupr.) Maxim.: P 31481

*Lonicera morrowii Gray: P 35649

Sambucus canadensis L.: P 31707

*Viburnum opulus L.: P 31552

Viburnum prunifolium L.: P 35667

\section{Caryophyllaceae}

*Arenaria serpyllifolia L.: P35647

*Cerastium fontanum Baum: P31497

Cerastium nutans Raf.: P31526

*Dianthus armeria L.: P31645

*Holosteum umbellatum L.: P31541

*Saponaria officinalis L.: E28915

Silene antirrhina L.: P31641

* Silene pratensis (Spreng.) Godron \& Gren.: P31495

*Stellaria media (L.) Cyrillo: P31496

\section{Celastraceae}

Celastrus scandens L.: P32674

\section{Chenopodiaceae}

*Chenopodium album L.: P32510

Chenopodium standleyanum Aellen: P32393

*Monolepis nuttalliana (Roem. \& Schultes) Greene: P35646

\section{Cistaceae}

Helianthemum bicknellii Fern.: P31595

Helianthemum canadense (L.) Michx.: P32668

Lechea intermedia Britt.: P37119

Lechea stricta Leggett: P32603

Lechea tenuifolia Michx.: E28958

Convolvulaceae

Calystegia sepium (L.) R. Br.: P31674

\section{Cornaceae}

Cornus obliqua Raf.: P31712

Cornus racemosa Lam.: P31714

Cornus sericea L.: P31544

\section{Corylaceae}

Corylus americana Walt.: P32519

\section{Crassulaceae}

*Sedum telephium L.: P36137

\section{Cucurbitaceae}

Echinocystis lobata (Michx.) Torr. \& Gray: P32436 


\section{Cuscutaceae}

Cuscuta gronovii Willd. var. gronovii: E28960

Cuscuta pentagona Engelm.: P32627

\section{Elaeagnaceae}

*Elaeagnus umbellata Thunb.: P31550

\section{Euphorbiaceae}

Acalypha gracilens Gray var. gracilens: P32529

Acalypha rhomboidea Raf.: E28899

Chamaesyce maculata (L.) Small: P32517

Chamaesyce nutans (Lag.) Small: P32439

Euphorbia corollata L.: E28945

Poinsettia dentata (Michx.) Kl. \& Garcke: P32656

\section{Fabaceae}

Amorpha canescens Pursh: E28941

Amorpha fruticosa L.: P31619

Amphicarpaea bracteata (L.) Fern. var. bracteata: observed

Apios americana Medic.: P32673

Astragalus canadensis L.: P34602

Baptisia alba (L.) Vent: E28952

Baptisia bracteata Ell. var. glabrescens (Larisey) Isely: P31490

Dalea purpurea Vent.: E28948

Desmodium canadense (L.) DC.: E28935

Desmodium illinoense Gray: P32443

*Kummerowia striata (Thunb.) Schind.: P32387

Lathyrus palustris L. var. palustris: P31692

Lespedeza capitata Michx.: P32422

*Lespedeza cuneata (Dum.-Cours.) G. Don: P32688

*Lotus corniculatus L.: P34674

*Medicago lupulina L.: P31498

* Medicago sativa L.: P31640

*Melilotus albus Medic.: P31648

*Melilotus officinalis (L.) Pallas: P31639

*Robinia pseudoacacia L.: P32575

Tephrosia virginiana (L.) Pers.: P31668

*Trifolium campestre Schreb.: P31722

*Trifolium hybridum L.: P31721

*Trifolium pratense L.: P31573

*Trifolium repens L.: P31488

*Vicia villosa Roth: P31636

\section{Fagaceae}

Quercus velutina Lam.: P31478

\section{Gentianaceae}

Gentiana andrewsii Griseb.: P32545

Gentiana puberulenta J. Pringle: P32640

\section{Grossulariaceae}

Ribes americanum Mill.: P31549

Ribes missouriense Nutt.: P34609 


\section{Hypericaceae}

Hypericum canadense L.: P32599

Hypericum gentianoides (L.) BSP.: P32665

*Hypericum perforatum L.: E28908

Hypericum punctatum Lam.: E28932

Hypericum sphaerocarpum Michx.: P32611

Triadenum fraseri (Spach) Gl.: P32447

\section{Juglandaceae}

Juglans nigra L.: P32618

\section{Lamiaceae}

*Chaiturus marrubiastrum (L.) Reichenb.: P32601

*Glechoma hederacea L.: P32658

Hedeoma hispida Pursh: P31627

*Lamium amplexicaule L.: P35645

*Leonurus cardiaca L.: E28911

Lycopus americanus Muhl.: P32361

Lycopus uniflorus Michx.: P32458

*Mentha arvensis L.: E28913

Monarda fistulosa L.: E28938

Monarda punctata L.: E28946

*Nepeta cataria L.: E28895

Physostegia speciosa (Sweet) Sweet: P34976

Physostegia virginiana (L.) Benth.: P32462

*Prunella vulgaris L.: E28912

Pycnanthemum virginianum (L.) Dur. \& B.D. Jacks.: E28925

* Salvia reflexa Hornem.: P32661

Scutellaria galericulata L.: P32500

Scutellaria lateriflora L.: P32355

Scutellaria leonardii Epling: P35665

Stachys pilosa Nutt. var. homotricha (Fern) Mohlenbr.: P31701

Teucrium canadense L.: E28923

\section{Linaceae}

Linum sulcatum Riddell: P32397

\section{Lythraceae}

Ammannia coccinea Rottb.: P32567

Lythrum alatum Pursh: P31672

* Lythrum salicaria L.: P32371

Rotala ramosior (L.) Koehne: P32597

\section{Malvaceae}

*Abutilon theophrastii Medic.: P32584

Hibiscus laevis All.: P32503

* Malva neglecta Wallr.: P31538

*Sida spinosa L.: P32583

\section{Melastomataceae}

Rhexia virginica L.: E28934

\section{Molluginaceae}

*Mollugo verticillata L.: E28890 


\section{Moraceae}

*Maclura pomifera (Raf.) Schneider: P32499

*Morus alba L.: P34606

*Morus tatarica L.: P34605

\section{Nyctaginaceae}

*Mirabilis nyctaginea (Michx.) MacM.: P31571

\section{Oleaceae}

Fraxinus pennsylvanica Marsh.: P31546

\section{Onagraceae}

Epilobium coloratum Spreng.: P32511

Epilobium leptophyllum Raf.: P32453

Gaura biennis L.: P32635

Ludwigia alternifolia L.: E28933

Ludwigia palustris (L.) Ell.: P32637

Ludwigia polycarpa Short \& Peter: P32356

Oenothera biennis L.: P32348

Oenothera clelandii W. Dietr., Raven, \& W.L. Wagner: E28951

\section{Orobanchaceae}

Orobanche ludoviciana Nutt.: P32607

\section{Oxalidaceae}

Oxalis stricta L.: P31486

Oxalis violacea $\mathrm{L} .: \mathrm{P} 31505$

\section{Phrymaceae}

Phryma leptostachya L.: P32386

\section{Phytolaccaceae}

Phytolacca americana L.: E28894

\section{Plantaginaceae}

Plantago aristata Michx.: P31684

*Plantago lanceolata L.: P31576

Plantago patagonica Jacq.: P32445

Plantago rugelii Decne.: P32351

\section{Polemoniaceae}

Phlox bifida Beck: P31524

Phlox maculata L.: P31699

\section{Polygalaceae}

Polygala polygama Walt.: P31559

Polygala sanguinea L.: E28930

Polygala verticillata L. var. isocycla Fern.: P32392

\section{Polygonaceae}

Antenoron virginianum (L.) Roberty \& Vautier: P32670

*Fallopia convolvulus (L.) A. Love: P34601

Fallopia scandens (L.) Holub: P32430

Persicaria amphibium (L.) S.F. Gray: E28922 
* Persicaria cespitosa (Blume) Nakai: P34604

Persicaria coccinea (Muhl.) Greene: P40241

* Persicaria hydropiper (L.) Opiz: P32624

Persicaria hydropiperoides (Michx.) Small: P31680

Persicaria lapathifolia (L.) S.F. Gray: P32512

Persicaria pensylvanica (L.) Small: P32362

Persicaria punctata (Ell.) Small: P32364

*Persicaria vulgaris Webb \& Moq.: P32651

Polygonum achoreum S.F. Blake: P34688

*Polygonum arenastrum Boreau: P32657

Polygonum ramosissimum Michx.: P32516

Polygonum tenue Michx.: P32398

*Rumex acetosella L.: P31533

Rumex altissimus Wood: P31689

*Rumex crispus L.: P31694

Rumex orbiculatus Gray: P32508

Tracaulon sagittatum (L.) Small: P32376

\section{Portulacaceae}

*Portulaca oleracea L.: E28892

Talinum rugospermum Holz.: P32558

\section{Primulaceae}

Lysimachia lanceolata Walt.: P32492

Lysimachia quadriflora Sims: P32465

Lysimachia thyrsiflora L.: P34975

\section{Ranunculaceae}

Anemone canadensis L.: P31591

Anemone cylindrica Gray: P32617

Anemone virginiana $\mathrm{L} .: \mathrm{P} 34680$

Caltha palustris L.: P31590

Ranunculus abortivus L.: P31509

Ranunculus longirostris Godr.: P31658

Ranunculus pensylvanicus L. f.: E28898

Ranunculus sceleratus L.: P32685

Thalictrum dasycarpum Fisch. \& Lall. var. hypoglaucum (Rydb.) Boivin: P31556

\section{Rhamnaceae}

*Rhamnus cathartica L.: P32647

\section{Rosaceae}

Agrimonia parviflora Sol.: E28893

Crataegus mollis (Torr. \& Gray) Scheele: P31631

Fragaria virginiana Duchesne: P31477

Geum canadense Jacq.: P31664

Geum laciniatum Murr.: P31700

Malus ioensis (Wood) Britt.: P31632

*Malus pumila Mill.: P31502

Physocarpus opulifolius (L.) Maxim.: P31709

*Potentilla argentea L.: P31517

Potentilla arguta Pursh: E28924

*Potentilla norvegica L.: P32505

*Potentilla recta L.: P31649 
Potentilla simplex Michx.: P31489

Prunus americana Marsh. var. americana: P31543

Prunus angustifolia Marsh.: P32493

Prunus pensylvanica L. f.: P35671

Prunus serotina Ehrh.: P31487

Prunus virginiana L.: P31521

* Rosa arkansana Porter: P32553

*Rosa damascena Mill.: P35671

Rosa carolina L.: P31594

* Rosa multiflora Thunb.: P31606

*Rosa spinosissima L.: P35670

Rubus allegheniensis Porter: P31623

Rubus flagellaris Willd.: P31600

Rubus occidentalis L. Bailey: P31534

Rubus pensilvanicus Poir.: P32498

Spiraea alba DuRoi: P32432

\section{Rubiaceae}

Diodia teres Walt.: E28954

Galium aparine L.: P31493

Galium obtusum Bigel.: P31688

*Galium pedemontanum (Bellardi) All.: P35653

Galium tinctorium L.: P32452

Galium triflorum Michx.: P31661

\section{Rutaceae}

Ptelea trifoliata L.: E28902

\section{Salicaceae}

Populus deltoides Marsh.: P31716

Populus grandidentata Michx.: P32677

Populus tremuloides Michx.: P32548

Salix amygdaloides Anderss.: P31548

Salix discolor Muhl.: P32475

*Salix fragilis L.: P32523

Salix humilis Marsh.: P32550

Salix interior Rowlee: P31547

Salix nigra Marsh.: P32620

\section{Santalaceae}

Comandra umbellata (L.) Nutt.: P31510

\section{Saxifragaceae}

Heuchera richardsonii $\mathrm{R}$. Br.: P31693

Penthorum sedoides L.: P32359

Saxifraga pensylvanica L.: P31586

\section{Scrophulariaceae}

Agalinis purpurea (L.) Pennell: P32470

Agalinis tenuifolia (Vahl) Raf.: P32472

Chelone glabra L.: P32513

Gratiola neglecta Torr.: P35669

Leucospora multifida (Michx.) Nutt.: P32536

Lindernia anagallidea (Michx.) Pennell: P32416

Mimulus ringens L.: P32502

Nuttallanthus canadensis (L.) D. Sutton: P31532

Pedicularis lanceolata Michx.: P32433

Penstemon pallidus Small: P31528

Scrophularia lanceolata Pursh: P31626 
*Verbascum thapsus L.: E28903

*Veronica arvensis L.: P31514

Veronica peregrina L.: P31515

Veronicastrum virginicum (L.) Farw.: E28927

\section{Solanaceae}

*Datura stramonium L.: P32649

Physalis subglabrata Mack. \& Bush: P32659

Physalis virginiana Mill.: P31596

Solanum carolinense L.: P32404

*Solanum dulcamara L.: P31691

Solanum ptychanthum Dunal: E28889

\section{Ulmaceae}

Celtis occidentalis L.: $\mathrm{P} 32388$

Ulmus americana L.: P32525

*Ulmus pumila L.: P32401

Ulmus rubra Muhl.: P31620

\section{Urticaceae}

Boehmeria cylindrica (L.) Sw.: E28921

Parietaria pensylvanica Muhl.: P31616

Pilea pumila (L.) Gray: P32528

Urtica gracilis Ait.: E28920

\section{Verbenaceae}

Phyla lanceolata (Michx.) Greene: P32535

Verbena bracteata Lag. \& Rodr.: P31603

Verbena hastata L.: E28939

Verbena stricta Vent.: E28904

Verbena urticifolia L.: P32547

\section{Violaceae}

Viola affinis LeConte: P31503

Viola lanceolata L.: P31506

Viola pedata L.: P31531

Viola pratincola Greene: P32579.1

Viola pubescens Ait.: P34611

*Viola rafinesquei Greene: P31522

Viola sagittata Ait.: P31472

Viola sororia Willd.: P32579.2

\section{Vitaceae}

Parthenocissus inserta (Kern.) K. Fritsch: P32396

Parthenocissus quinquefolia (L.) Planch.: P32543

Vitis riparia Michx.: P31621

\section{Zygophyllaceae}

Tribulus terrestris L.: P34693 

University of Illinois

Institute of Natural Resource Sustainability

William Shilts, Executive Director

Illinois Natural History Survey

Brian D. Anderson, Director

Forbes Natural History Building

1816 South Oak Street

Champaign, Illinois 61820

217-333-6880 